\title{
Stratigraphy and tectonic history of the Upper Devonian to Lower Carboniferous Horton Bluff Formation, Nova Scotia
}

\author{
A. Thomas Martel and Martin R. Gibling \\ Department of Earth Sciences, Dalhousie University, Halifax, Nova Scotia B3H 3J5, Canada
}

Date Received July 19, 1995

Date Accepted August 15, 1995

The Devonian-Carboniferous Horton Group in the Maritimes Basin of Atlantic Canada was deposited in local half grabens during an extensional phase that followed the Acadian Orogeny. In its type area, the southwest part of the Minas Basin, the Horton Group is divided in ascending order into the Horton Bluff and Cheverie formations. Four members of the Horton Bluff Formation are formally defined here. The basal Harding Brook Member, of latest Devonian to early Tournaisian age, is a braided-fluvial sandstone unit developed above a paleosol on the underlying Meguma Group. The succeeding three members are shale/sandstone units of Tournaisian age. The Curry Brook Member was deposited in deltaic channels and interdistributary lakes, whereas the Blue Beach and Hurd Creek members were deposited in large, wave-dominated lakes and/or restricted-marine bays, with evidence of deltaic input for the Hurd Creek Member. The overlying Cheverie Formation is a coarse grained alluvial deposit of Tournaisian age.

Sediment style reflects an interaction between sediment flux, subsidence controlled accommodation space, and climate. Fluvial systems extended across the basin during periods of basin overfilling and fluvial/lacustrine/ estuarine deposits were laid down during periods of basin underfilling.

Evidence of a northward thickening and facies change suggests that the Horton Bluff Formation was deposited in a half-graben bounded to the north by the Cobequid Fault or a precursor fault. Paleoflow was northward, across the Meguma Terrane, during deposition of the alluvial deposits.

The late Devonian age for the basal Horton Group places an upper age limit on "docking" of the Meguma and Avalon terranes in the area, and suggests that Meguma rocks were rapidly exhumed prior to formation of extensional basins. The alluvial-lacustrine-alluvial succession in the Horton Group type area can be recognized in half grabens across Atlantic Canada, with a coeval (late Tournaisian) lacustrine phase. The widespread occurrence of this subsidence phase implies that the local, basin-bounding faults were components of a regional detachment at mid-crustal depth.

Le Groupe de Horton du Dévonien-Carbonifère du bassin des Maritimes, dans les provinces Atlantiques, s'est déposé dans des demi-fossés d'effondrement locaux au cours d'une phase de distension qui a suivi l'orogenèse acadienne. Dans son secteur type, la partie sud du bassin Minas, le Groupe de Horton est divisé, dans un ordre ascendant, en formations de Horton Bluff et de Cheverie. Quatre membres de la Formation de Horton Bluff sont officiellement définis aux présentes. Le membre basal, le membre du ruisseau Harding, de l'époque du Dévonien supérieur au début du Tournaisien, est une unité de grès fluviale anastomosée qui s'est développée au-dessus d'un paléosol sur le Groupe sous-jacent de Meguma. Les trois membres suivants sont des unités de schiste / grès remontant au Tournaisien. Le membre Curry Brook s'est déposé dans des canaux deltaïques et des lacs interbras, tandis que les membres Blue Beach et Hurd Creek se sont déposés dans des lacs étendus dominés par des eaux agitées ou des baies marines restreintes, avec la preuve d'un apport deltaïque dans le cas du membre Hurd Creek. La Formation sus-jacente de Cheverie est un gîte alluvionnaire à gros grain de l'époque du Tournaisien.

Le style de sédimentation témoigne d'une interaction entre le ruissellement sédimentaire, la superficie d'accueil déterminée par l'effondrement, et le climat. Des réseaux fluviaux traversaient le bassin pendant les périodes de débordement du bassin et des dépôts fluviaux / lacustres / estuariens se sont établis pendant les périodes de faible remplissage du bassin.

Une preuve d'un changement de faciès et d'un épaississement en direction nord laisse supposer que la Formation de Horton Bluff s'est déposée dans un demi-fossé d'effondrement délimité au nord par la faille de Cobequid ou une faille annonciatrice. Le paléoécoulement s'est dirigé vers le nord, à travers la terrane de Meguma, au cours de la sédimentation des gîtes alluvionnaires.

L'âge du Groupe basal de Horton, fixé au Dévonien tardif, limite l'âge maximal de " l'arrivée " des terranes de Meguma et d'Avalon dans le secteur, et il permet de supposer que les roches de Meguma ont rapidement été exhumées avant la formation des bassins de distension. On peut repérer la succession alluvionnaire-lacustrealluvionnaire du secteur type du Groupe de Horton dans des demis-fossés partout dans les provinces Atlantiques, en compagnie d'une phase lacustre contemporaine (Tournaisien supérieur). La présence répandue de cette phase d'effondrement laisse supposer que les failles locales de délimitation du bassin constituaient des composantes d'un détachement régional à mi-profondeur de la croûte terrestre.

[Traduit par la rédaction] 


\section{INTRODUCTION}

The Horton Group is an important Devonian-Carboniferous stratigraphic unit in Atlantic Canada. The group and coeval but differently named units are known from an area $1000 \mathrm{~km}$ long and $400 \mathrm{~km}$ wide (Sanford and Grant, 1990), and has been correlated with strata of similar age and depositional environment in the British Isles (Belt, 1969). The Horton Group in the type area near Wolfville, Nova Scotia, rests with pronounced unconformity on Lower Paleozoic rocks of the Meguma Terrane and thus post-dates terrane accretion associated with the Acadian Orogeny in this area (Bell, 1929; Keppie et al., 1983). Typical of the Horton Group are thick conglomerate, shale and sandstone successions that were deposited in alluvial fans, rivers, deltas and perennial lakes or brackish bays within a series of rifted subbasins (Fig. 1) that persisted for significant periods over much of the Maritimes Basin (Belt, 1968a; Hyde et al., 1988; Hamblin and Rust, 1989). Thick, organic-rich shales and porous sandstones and conglomerates that are present at many localities make the Horton Group an important prospective hy- drocarbon source and reservoir (Martel, 1987; Carter and Pickerill, 1985; Utting and Hamblin, 1991). Seeps are known and oil has been produced form Horton Group equivalents at Stony Creek, New Brunswick.

The southwestern Minas Basin area, spanning the Avon River estuary (Fig. 2), was designated the type area of the Horton Group by Bell (1929). The area contains some of the best exposures of the group within the Maritimes Basin due to wide wave-cut platforms and tall cliffs. The Horton Bluff Formation is important for understanding the development of the Maritimes Basin immediately following the Acadian Orogeny. It also occupies one of the most structurally complicated areas adjacent to the Cobequid-Chedabucto Fault Zone. Bell (1960) divided the Horton Group into a lower Horton Bluff and an upper Cheverie Formation, and subdivided the former into informal basal, middle, and upper members (Table 1). However, neither he nor subsequent workers presented a complete stratigraphic log for the Horton Bluff type section, nor did they define formal members.

We here provide a detailed, composite section of the Horton Bluff Formation within the type area, and formally

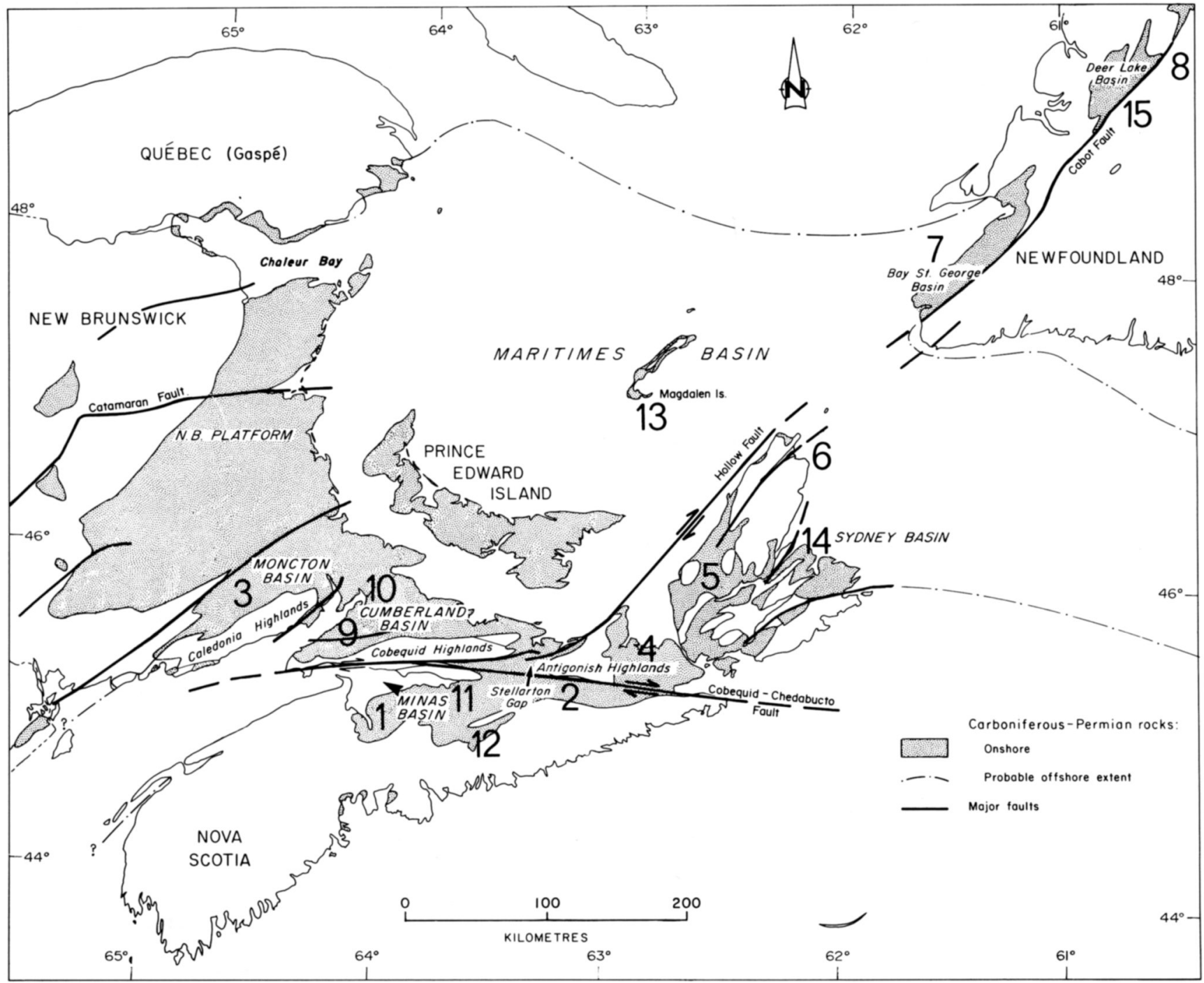

Fig. 1. Map of the Maritimes Basin of Atlantic Canada to show the area underlain by Middle Devonian to Permian rocks (stippled). Subbasins are numbered: (1) Windsor, (2) St. Mary's, (3) Moncton, (4) Antigonish, (5) Cape Breton South, (6) Cape St. Lawrence, (7) Bay St. George, (8) White Bay, (9) Cumberland, (10) Sackville, (11) Shubenacadie, (12) Musquodoboit, (13) Magdalen, (14) Sydney, and (15) Deer Lake. 


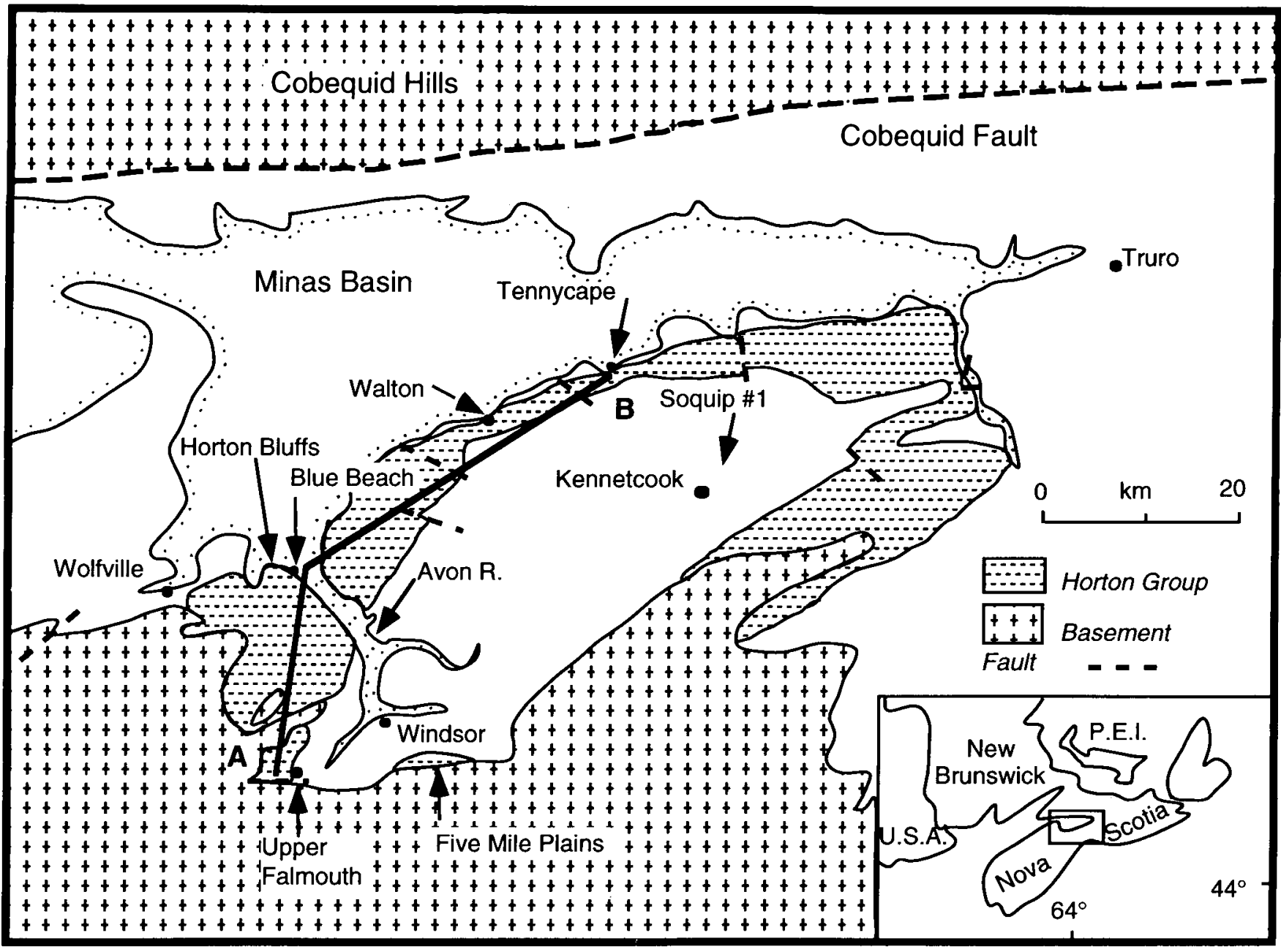

Fig. 2. Geological map of study area (Windsor Subbasin). Basement is composed of undifferentiated Meguma Group and granitic rocks south of the Cobequid Fault (Meguma Terrane), and granitic, metamorphic and sedimentary rocks north of the Cobequid Fault (Avalon Terrane). The Horton Group includes the Horton Bluff and Cheverie formations. Unpatterned areas onshore indicate younger Carboniferous and Mesozoic rocks. Cross section along line A-B is shown in Figure 3.

propose four locally significant members using coastal and stream exposures, supplemented by drill core (see Appendix 1). This stratigraphic framework provides a useful basis for discussing the Late Devonian to Early Carboniferous tectonic history of the Windsor Subbasin area.

\section{Horton Group in the Windsor Subbasin}

\section{Distribution}

Figure 2 shows the present-day erosional remnant of the Horton Group within the Windsor Subbasin. The strata thin and onlap southward onto the Cambrian-Ordovician Meguma Group and Late Devonian granitic intrusives of the South Mountain Batholith. The original extent of the subbasin to the west is unknown, although southwestward thinning suggests a nearby basin edge. Seismic data show that Horton Group strata extend northward under the modern Minas Basin, probably as far as the present-day line of the Cobequid Fault. East of Truro, the Horton Group crops out extensively in the St. Mary's Subbasin, although the relationship of these rocks to the Windsor Subbasin is uncer- tain. Small, faulted areas of poorly dated rock that may be coeval with the Horton Group are present in the Cobequid Hills north of the Cobequid Fault, and have been mapped informally as the Greville River, Nuttby, and Rapid Brook formations (Donohoe and Wallace, 1982).

\section{Age}

A Tournaisian age for most of the Horton Bluff Formation and all of the Cheverie Formation was assigned using miospores (Playford, 1963; Hacquebard, 1972; Utting, 1987; Utting et al., 1989; Martel et al., 1993), megaflora, and invertebrates (Bell, 1960). Utting et al. (1989) recognized two miospore assemblage zones within the Horton Group of the Windsor Subbasin and correlated these zones with miospore zones (and stages) (Clayton, 1985) of western Europe. Martel et al. (1993) documented two additional assemblage zones, and for the first time established the presence of upper Devonian strata in the type area. The oldest of these zones in the Horton Bluff Formation is dated as Strunian (topmost Famennian, Late Devonian), whereas the youngest is dated as Late Tournaisian (Early Carboniferous) (Utting et al., 
Table 1. Stratigraphic nomenclature used here and by previous authors for the Horton Bluff Formation. Offsets between correlations indicate different positions for member boundaries (see Martel, 1990).

\begin{tabular}{|c|c|c|c|}
\hline $\begin{array}{l}\text { Bell 1929, } \\
1960\end{array}$ & Worth 1969 & $\begin{array}{l}\text { Ferguson } 1983 \\
\text { Moore and } \\
\text { Ferguson } 1986\end{array}$ & This Paper \\
\hline $\begin{array}{l}\text { Upper Member } \\
120 \mathrm{~m}\end{array}$ & \multirow{2}{*}{$\begin{array}{l}\text { Upper } \\
\text { Sandst one } \\
120 \mathrm{~m}\end{array}$} & \multirow[t]{2}{*}{ Upper Member } & $\begin{array}{l}\text { Hurd Creek } \\
\text { Member }\end{array}$ \\
\hline \multirow{3}{*}{$\begin{array}{l}\text { Middle Member } \\
\text { (upper } \\
\text { portion) } \\
350+\mathrm{m} \\
---- \\
\text { Middle Member } \\
\text { (lower } \\
\text { portion) }\end{array}$} & & & $300 \mathrm{~m}$ \\
\hline & $\begin{array}{l}\text { Middle } \\
\text { Sandst one } \\
\text { (middle shale } \\
\text { facies) } \\
360 \mathrm{~m} \text { ) }\end{array}$ & Middle Member & $\begin{array}{l}\text { Blue Beach } \\
\text { Member } \\
210+m\end{array}$ \\
\hline & $\begin{array}{l}\text { Middle } \\
\text { Sandst one } \\
\text { (Curry Brook } \\
\text { sandst one } \\
\text { facies) } \\
450 \mathrm{~m}\end{array}$ & \multirow[t]{2}{*}{ Lower Member } & $\begin{array}{l}\text { Curry Brook } \\
\text { Member } \\
120+m\end{array}$ \\
\hline $\begin{array}{l}\text { Basal Member } \\
180 \mathrm{~m}\end{array}$ & $\begin{array}{l}\text { Gaspereau } \\
\text { Sandst one } \\
90 \mathrm{~m}\end{array}$ & & $\begin{array}{l}\text { Harding Brook } \\
\text { Member } \\
100 \mathrm{~m}\end{array}$ \\
\hline
\end{tabular}

1989; Martel et al., 1993). Palynological analysis suggests that a hiatus spanning the latest Tournaisian and early Visean is present between the Cheverie Formation and the overlying, evaporitic, marine Windsor Group; however, such a hiatus may be more apparent than real, in view of the presence of redbeds lacking palynomorphs at the top of the Horton Group (Utting et al., 1989) and the scarcity of productive rocks in the evaporite-dominated Windsor Group.

\section{Horton BLuff Formation}

\section{Lithostratigraphy}

A compilation of four detailed sections indicates a thickness of at least $525 \mathrm{~m}$ for the Horton Bluff Formation in the type area near Hantsport, on the west side of the Avon River (Fig. 3; see also Martel, 1990). A summation of maximum member thicknesses totals $730 \mathrm{~m}+$. Drill logs of Saarberg Interplan 


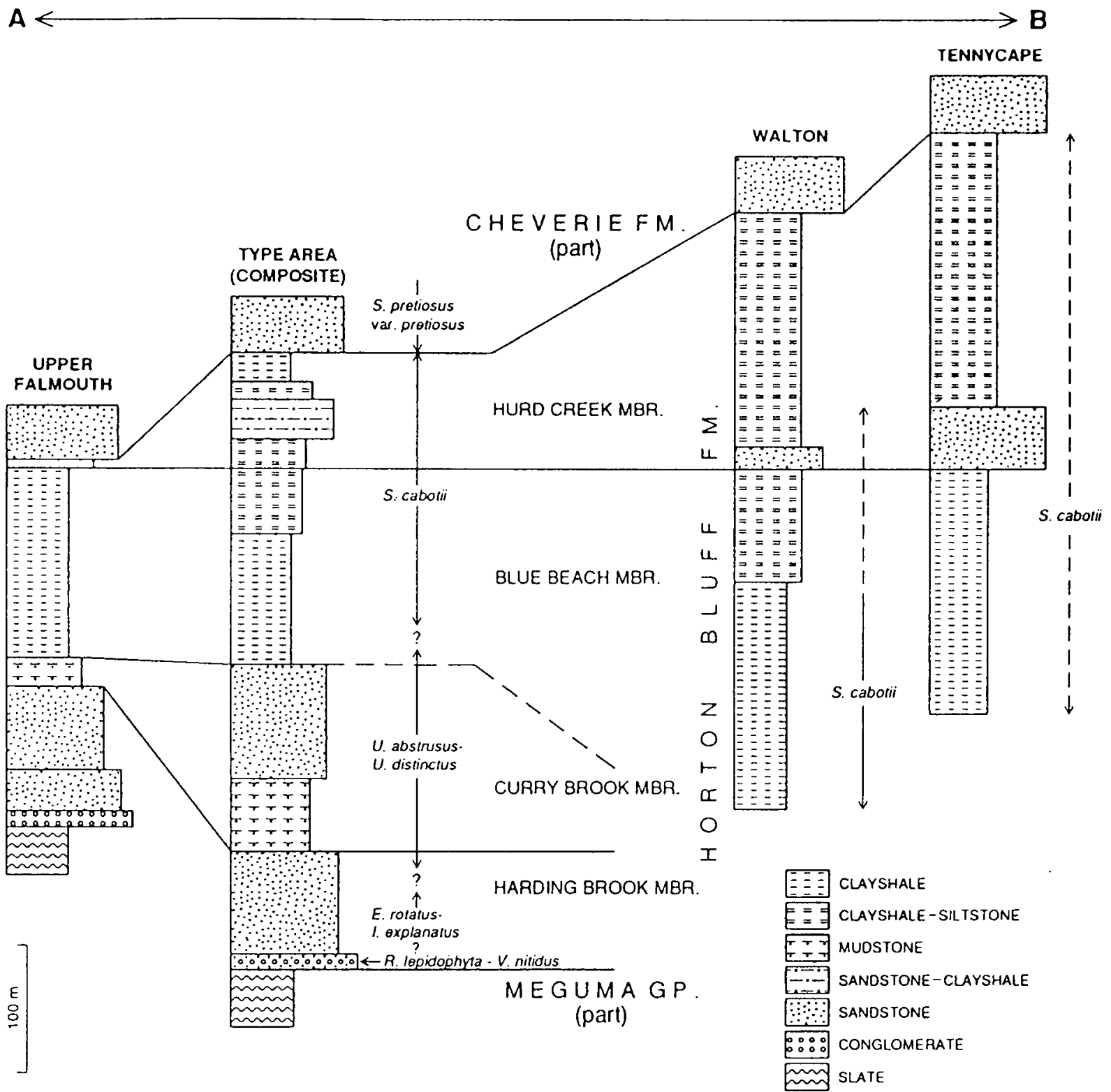

Fig. 3. Palynological zonation of the Horton Group in the southern part of the Windsor Subbasin. The four members of the Horton Bluff Formation have type areas on the western side of the Avon River estuary and together make up the composite column for the type area. Miospore zones (Utting et al., 1989; Martel et al., 1993) are: Retispora lepidophyta - Verrucosisporites nitidus Zone (Famennian: Late Devonian); Emphanisporites rotatus - Indotritadites explanatus Zone (early Tournaisian: Early Carboniferous); Umbonatisporites abstrusus - U. distinctus and Spelaeotriletes cabotii Subzones (late Tournaisian); and Spelaeotriletes pretiosus Zone (late Tournaisian). A-B in Figure 2 denotes line of cross-section.

Canada Limited (Quarch et al., 1979) indicate that the formation thins southwestward to $350 \mathrm{~m}$ in the Upper Falmouth area (Fig. 3), and pinches out in the Five Mile Plains area (Fig. 2). A Horton Bluff section $1015 \mathrm{~m}$ thick was intersected in the 1975 Soquip Noel \#1 well at Kennetcook (Figs. 2, 4). Lithologic sections and seismic data (see Martel, 1990, fig. 1.5) indicate that Horton Group strata thicken substantially northeast of the well toward the Cobequid Fault.

\section{Previous Stratigraphy}

The assignment of member names to Horton Bluff units has varied significantly in the past. The following is a history of those assignments and their relationship to the member units used in this paper: Martel (1990) provides a more detailed historical review. The strata that comprise the Horton Bluff Formation were first described by Jackson and Alger $(1828,1829)$. Bell $(1929)$ defined the term Horton Series and divided it into the Horton Bluff and Cheverie formations (Table 1). He also defined basal, middle, and upper members of the Horton Bluff Formation. Bell (1960) changed the Horton Series to Horton Group, described the three Horton Bluff members in more detail, and subdivided the middle member into a lower sandstone and an upper shale unit. Worth (1969) informally replaced the basal, middle, and upper members with the Gaspereau sandstone, middle sandstone, and upper sandstone, respectively, and further divided these members into facies (see Table 1). MacDonald (1973) sug- 


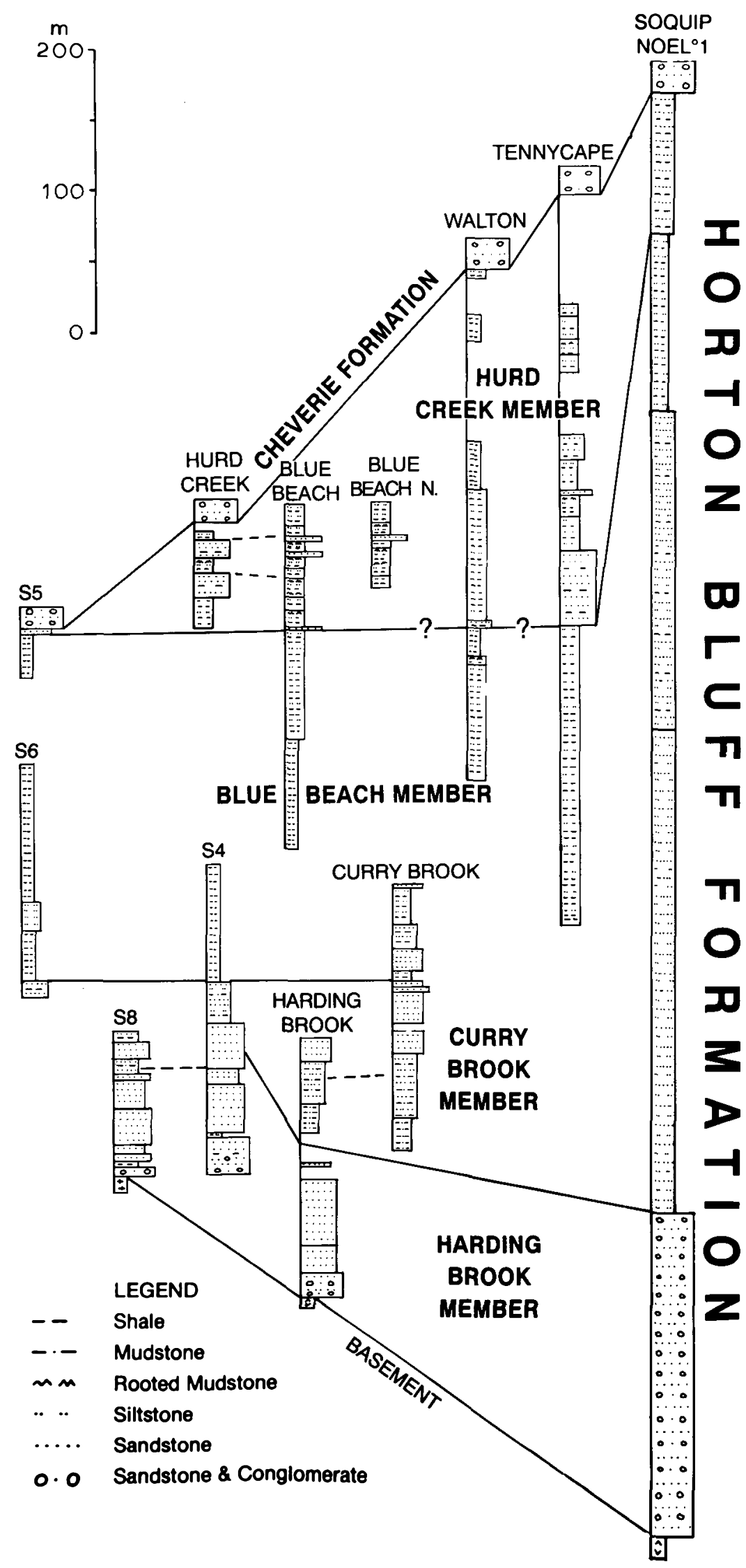

Fig. 4. Geological cross-section of the Horton Bluff Formation in the Windsor Subbasin. Solid lines represent member or formational boundaries. Datum is taken at the Hurd Creek/Blue Beach boundary. Saarberg drill holes S4, S5, S6 and S8 are located just west of Upper Falmouth (Fig. 2). See Figures 2 and $S$ for section locations, and Moore and Ferguson (1986) for location of the Saarberg drill holes. 
gested that the section at Blue Beach contains strata of the middle member only, in contrast to Bell's (1960) placement of the strata in both the middle and upper members.

Ferguson (1983) and Moore and Ferguson (1986) provided detailed maps of the western portion of the Windsor Subbasin. They adopted a lower (as opposed to Bell's basal), middle, and upper member terminology, but mapped divisional boundaries that do not correspond in geographic or stratigraphic position to those described by Bell (1960) (Table 1). Correlation of stratigraphic sections measured during this study with field descriptions summarized by Bell (1960), indicates that the above authors placed the lower portion of Bell's middle member into the upper portion of their lower member (Table 1) and followed MacDonald (1973) in placing the entire Blue Beach section within the middle member. We agree with Bell (1960), however, that this section consists of both the middle and upper members (see below). Whereas Bell (1960) chose member boundaries based on rock-type and presence or absence of ostracodes, we found this difficult to apply and based the Curry Brook/Blue Beach and Blue Beach/Hurd Creek boundaries solely on distinctive changes in the rock character, using fossil occurrences as supporting evidence.

We believe that the four stratigraphic units recognized by Bell $(1929,1960)$ in the type area are distinctive and, with slight modification (see below), warrant status as formal members (Table 1). These four units are, from bottom to top, the Harding Brook, Curry Brook, Blue Beach and Hurd Creek members. Palynological zonation (Fig. 3) supports the validity of member designation to outlying, highly deformed outcrop belts at Walton and Tennycape; however, biostratigraphic evidence is not used as a criterion for formal definition of the members. The lithostratigraphy and depositional environments of each member are discussed below, and descriptions of the type section, correlative sections, boundaries, and age are found in Appendix 1.

\section{Harding Brook Member}

\section{Lithology}

The Harding Brook Member contains the coarsest sediments within the Horton Bluff Formation in the type area. The member is dominated by sandstone and contains varying amounts of conglomerate, siltstone and mudstone. Maximum clast size within the sandstones and conglomerates generally decreases upward from granule to medium grained sand. Larger clasts are composed of milky vein quartz, quartz and feldspar derived from the South Mountain Batholith. The member is divided into four lithostratigraphic intervals, A through $\mathrm{D}$, each characterized by a distinct depositional style.

The basal breccia interval (A) (Bell, 1929; Worth, 1969), about $3 \mathrm{~m}$ thick, is absent at Harding Brook, but commonly rests unconformably upon rocks of the Meguma Terrane in other areas, including Duncanson Brook. The breccia appears structureless and consists of angular, granule- to pebblesized clasts of Meguma slates, feldspar and quartz supported within a clay matrix. Rhizoliths are common, and the rock shows a conchoidal to irregular weathering pattern. At Harding Brook, the slates of the Meguma Group basement below the angular unconformity are red-brown to green, in contrast to its usual grey.

At Harding Brook (Figs. 5, 6), interval (A) is missing, and the basal unconformity is overlain by a broadly finingupward conglomeratic interval (B) (0-34 m: "fluvial facies" of Worth, 1969) that consists of repeated fining-upward successions, 1 to $4 \mathrm{~m}$ thick. The interval commences with a massive, clay-rich granule to pebble conglomerate, associated with tabular units of trough and planar cross-bedded sandstone (Fig. 7) up to $2 \mathrm{~m}$ thick. The sandstone beds are separated by beds of pedoturbated, carbonaceous silt/claystone 5 to $10 \mathrm{~cm}$ thick. These strata are commonly overlain by ripple cross-laminated sandstone in tabular beds up to 30 cm thick. Many successions are capped by carbonaceous and micaceous siltstones, up to $1 \mathrm{~m}$ thick, that are planar-bedded or featureless (probably disrupted by roots).

A relatively uniform, cross-bedded, medium- to coarsegrained, quartzose sandstone interval (C) (34-78 m) consists of successions 1 to $7 \mathrm{~m}$ thick. Most successions fine upward slightly from coarse- to medium-grained sandstone, which is abruptly overlain by pedoturbated mudstone. The successions have erosional bases with up to $55 \mathrm{~cm}$ of relief. Trough cross-sets predominate, with less common ripple crosslamination and rare planar cross-sets. Very thinly planarlaminated mudstone forms units up to $3 \mathrm{~m}$ thick. The successions are generally thicker and more uniform in terms of grain-size and grain-size trends than those of interval B (Fig. 6). Interval $C$ weathers to a reddish-brown.

A distinctive planar-bedded, fine grained sandstone interval (D) (78 to approximately $106 \mathrm{~m}$ ) is poorly exposed on Harding Brook, but is well represented in drill core S4 between 146.5 to $157.5 \mathrm{~m}$. Coarsening-upward successions, up to $13 \mathrm{~m}$ thick, typically commence with planar and ripple cross-laminated sandstone and contain abundant carbonaceous and clay partings. They are abruptly overlain by cross-bedded sandstones.

\section{Depositional Environment}

Interval A, the basal breccia, is interpreted as a paleosol developed at the basal unconformity, based on its structureless nature and the presence of rhizoliths. In view of its sharp basal contact, it is included within the Horton Bluff Formation. The discolouration of the Meguma Group rocks below the unconformity is interpreted as the result of weathering. Intervals $\mathrm{B}$ and $\mathrm{C}$, conglomerate and quartzose sandstone, are interpreted as the deposits of bedload-dominated, braided streams, based on the minor proportion of overbank deposits and the apparent absence of lateral accretion sets (Miall, 1977). The thin mudstone units probably were deposited on local floodplains, vegetated islands, and abandoned channels (Cant and Walker, 1978; Rust and Gibling, 1990). Interval $C$ contains thicker bedsets and successions than Interval $B$ and less mudstone. The more limited grain-size variation and the predominance of cross-bedded sandstone suggest a deeper, more continuously active channel system 

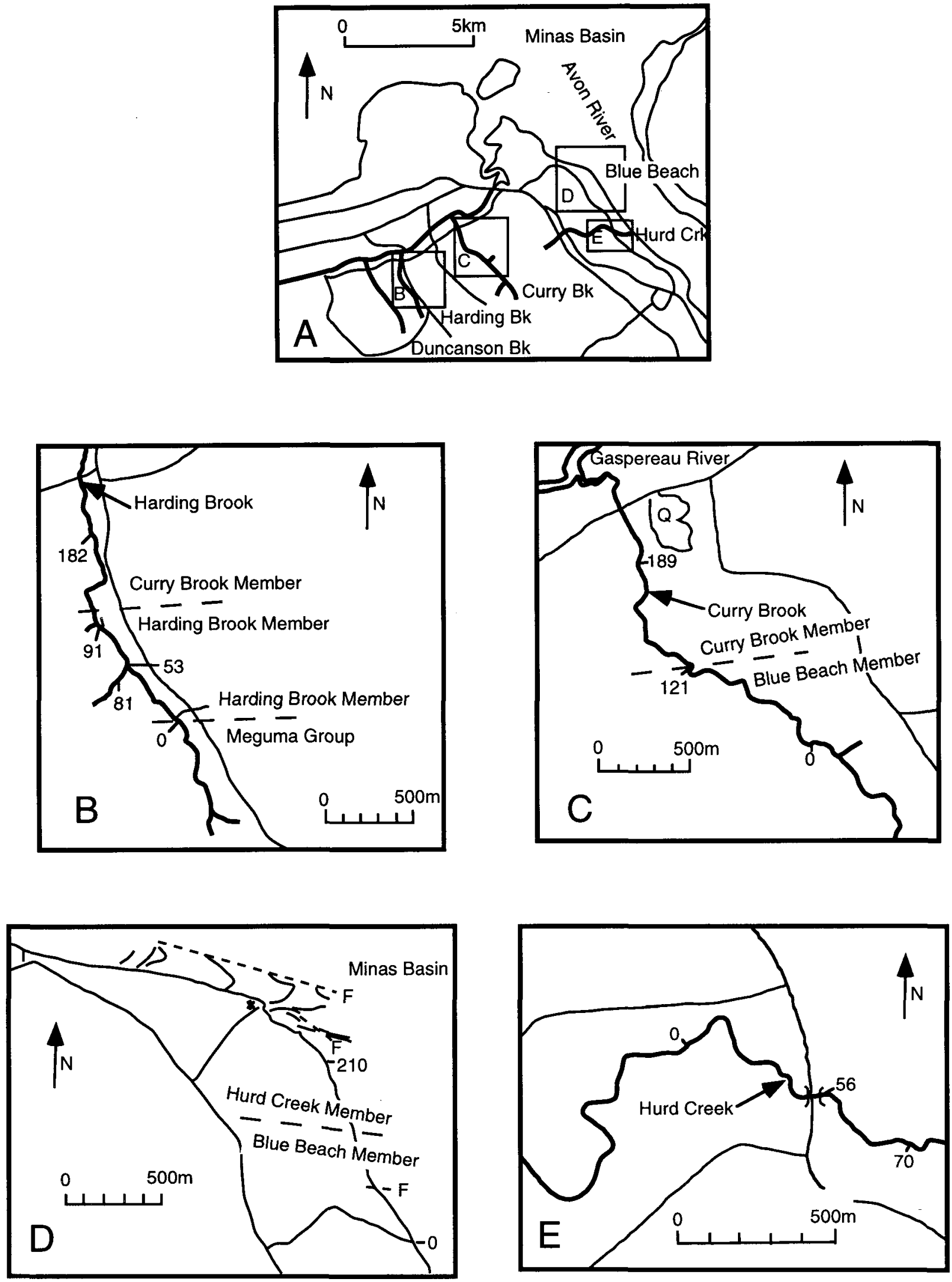

Fig. 5. Map A shows the location of key stratigraphic sections measured in the western portion of the Windsor Subbasin. (B) Harding Brook section (Fig. 6), (C) Curry Brook section (Fig. 8), (D) Blue Beach section (Fig. 10), (E) Hurd Creek section (Fig. 13). Numbers correspond to metres in the appropriate measured sections. Thick and thin solid lines represent streams and roads, respectively. $\mathrm{Q}=$ quarry, $\mathrm{F}=$ faults, * lighthouse. 


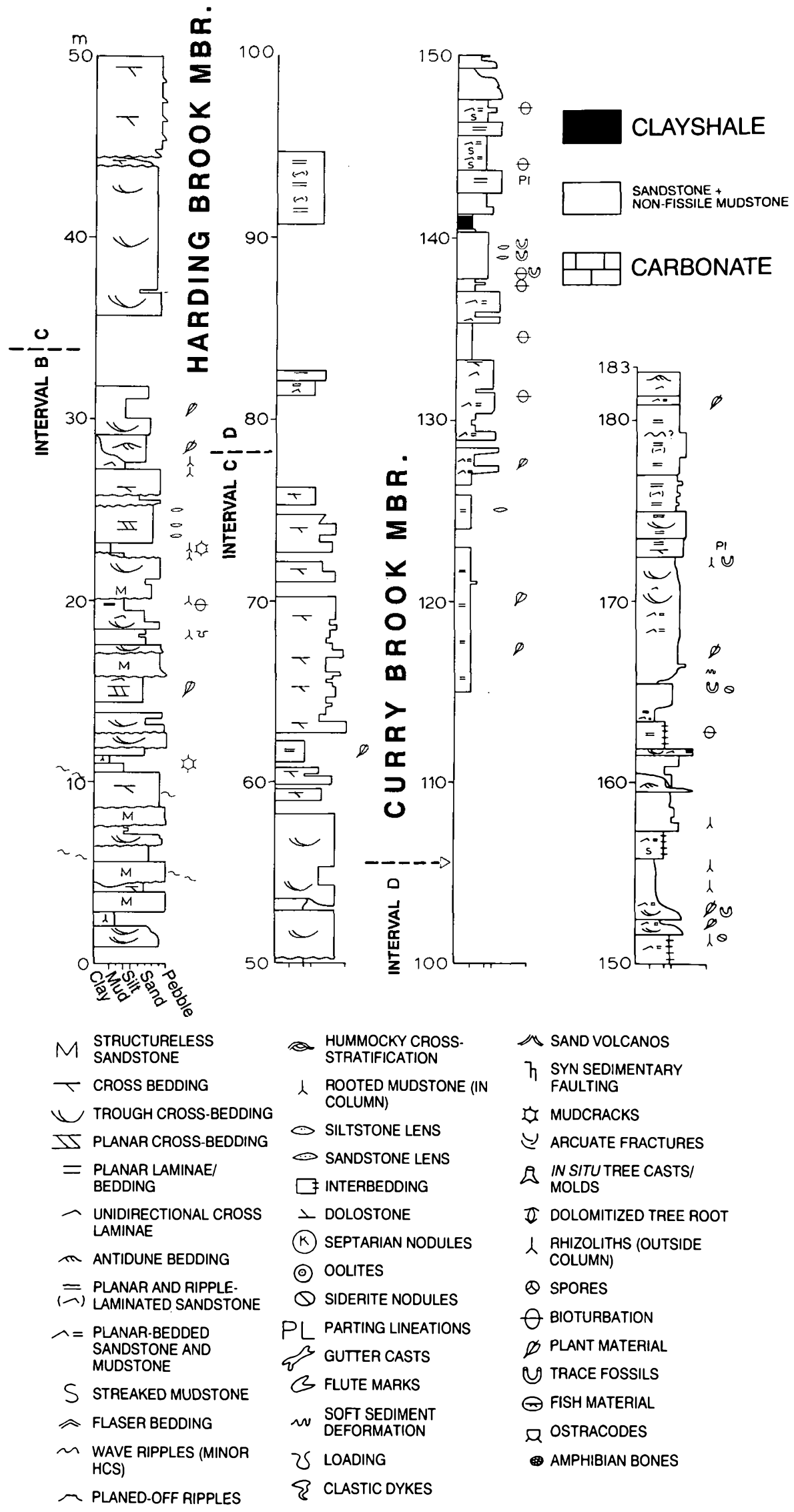

Fig. 6. Lithologic log of the Harding Brook section. See Figure 5 for location. 


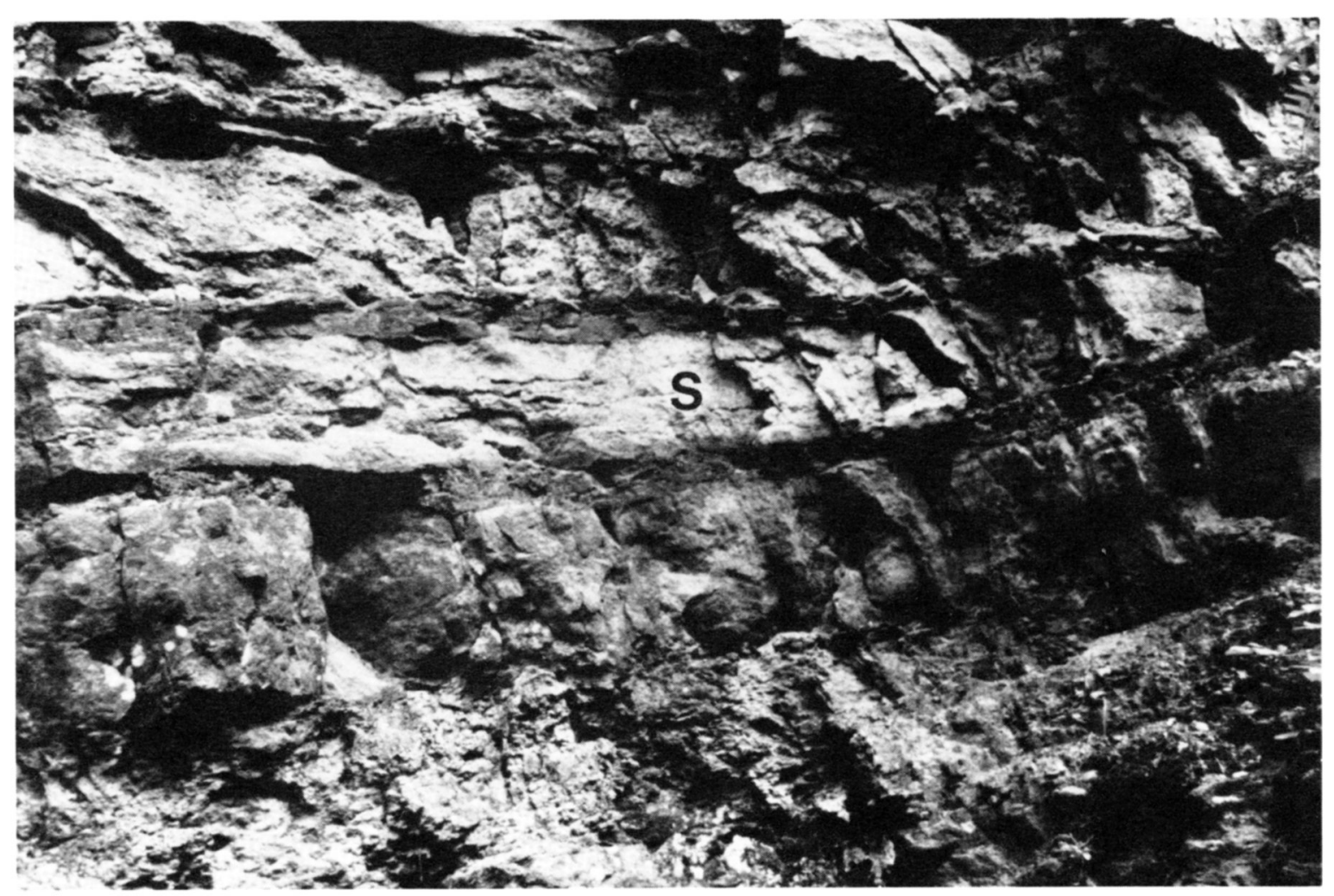

Fig. 7. Harding Brook Member. Planar-tabular sandstone packages (light grey) bounded at base and top by mudstone layers (darker grey). The middle sandstone package (S) is about $50 \mathrm{~cm}$ thick.

(Tunbridge, 1981). Fines were either not deposited or were removed by channel cutting. The upward coarsening successions of Interval D, planar fine grained sandstone, were deposited by traction-dominated streams entering standing bodies of water. They are interpreted as proximal delta deposits, with overlying cross-bedded sandstones interpreted as distributary channel deposits.

\section{Curry Brook Member}

\section{Lithology}

The Curry Brook Member is composed mainly of 1 to 4 $\mathrm{m}$ thick, coarsening-upward cycles that generally begin with mudstone and coarsen upward into sandstone (Figs. 5, 8). The basal mudstone is featureless, and probably bioturbated, or contains siltstone or sandstone laminae that increase in proportion upward; organic-rich layers and sideritic nodules are present. The mudstone passes up into alternate mudstone and planar-bedded sandstone and siltstone (Fig. 9A), in units up to $5 \mathrm{~m}$ thick that tend to coarsen and show an increased proportion of ripple cross-lamination toward the top. The cycles are capped by tabular, coarsening-upward units, 0.5 to $2 \mathrm{~m}$ thick, of ripple cross-laminated, fine- to very coarsegrained sandstone that are commonly gradationally based. Cross-bedded sandstone is present locally at cycle tops. Some mudstones within the cycles contain abundant plant detritus.

Associated with the cycles are thick (up to $6 \mathrm{~m}$ ) units of erosionally based, planar-bedded sandstone (Fig. 9B). The sandstone is fine- to medium-grained. Planar stratification (usually with parting lineation) and large-scale trough crossstratification are the predominant sedimentary structures.

In general, the lower part of the Curry Brook section $(0-25 \mathrm{~m})$ is dominated by mudstone, the middle part (25-69 $\mathrm{m})$ by interbedded siltstone and sandstone, and the top (69$121 \mathrm{~m}$ ) by very fine- to medium-grained sandstone (Fig. 8). Paleocurrent readings based on large-scale trough cross-beds and ripple cross-lamination indicate a mainly north-northeast to north-northwest direction of flow.

\section{Depositional Environment}

The coarsening-upward mudstone to sandstone cycles resemble, in many respects, the deposits of Holocene interdistributary lakes and bays of the Mississippi Delta, progressively infilled by crevasse splays and minor deltas (Coleman et al., 1964; Tye and Coleman, 1989). Similar distributary channel and interdistributary lake and bay environments were inferred for some British Upper Carboniferous strata by Fielding (1984).

\section{Blue Beach Member}

\section{Lithology}

The Blue Beach Member is characterized by an abundance of grey clay shale, ostracodes, and disarticulated fish material. In addition, the occurrence of dolomitic concretions and beds and the lack of non-stratified mudrocks, thick 


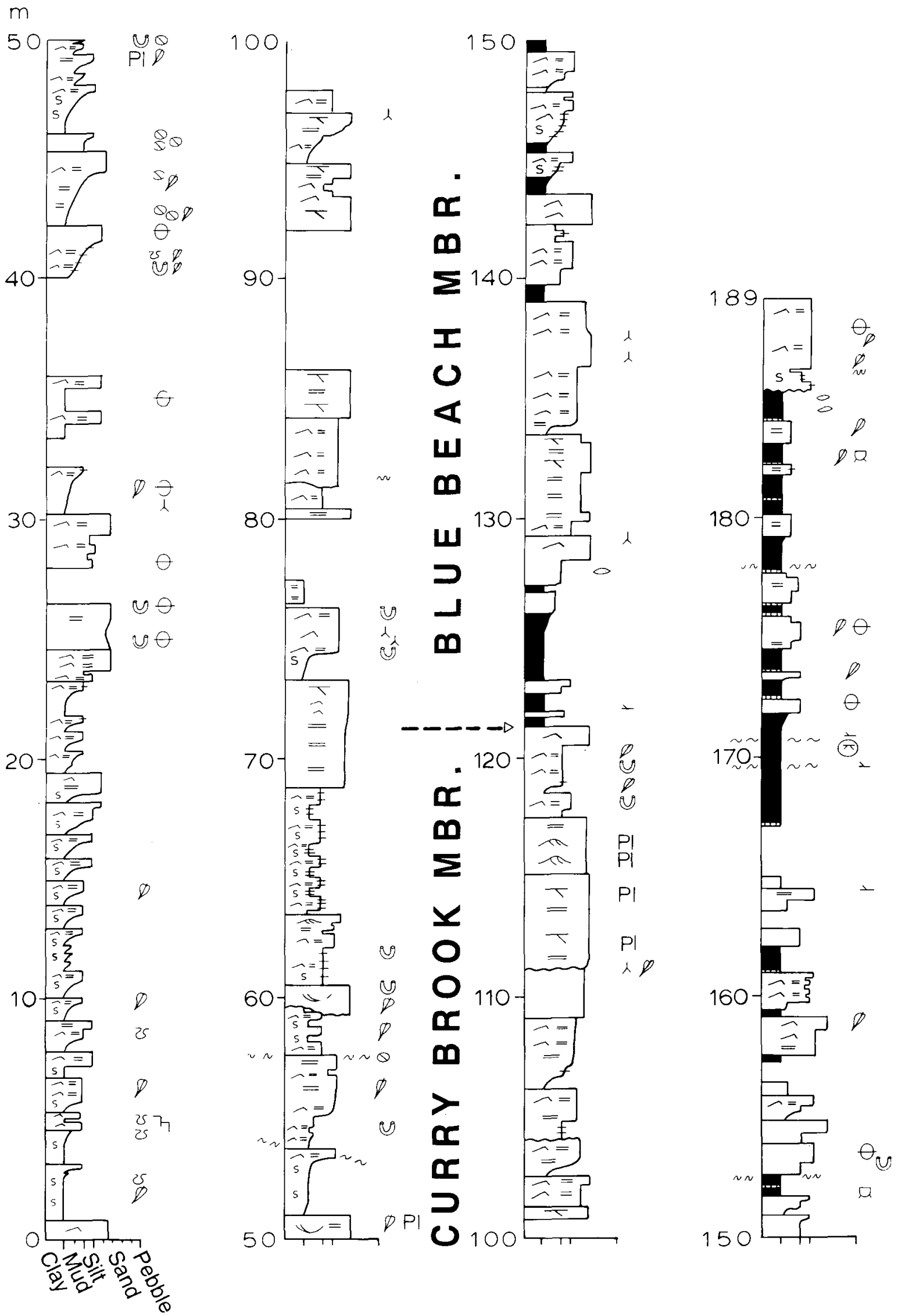

Fig. 8. Lithologic log of the Curry Brook section. See Figure 5 for location and Figure 6 for legend. 

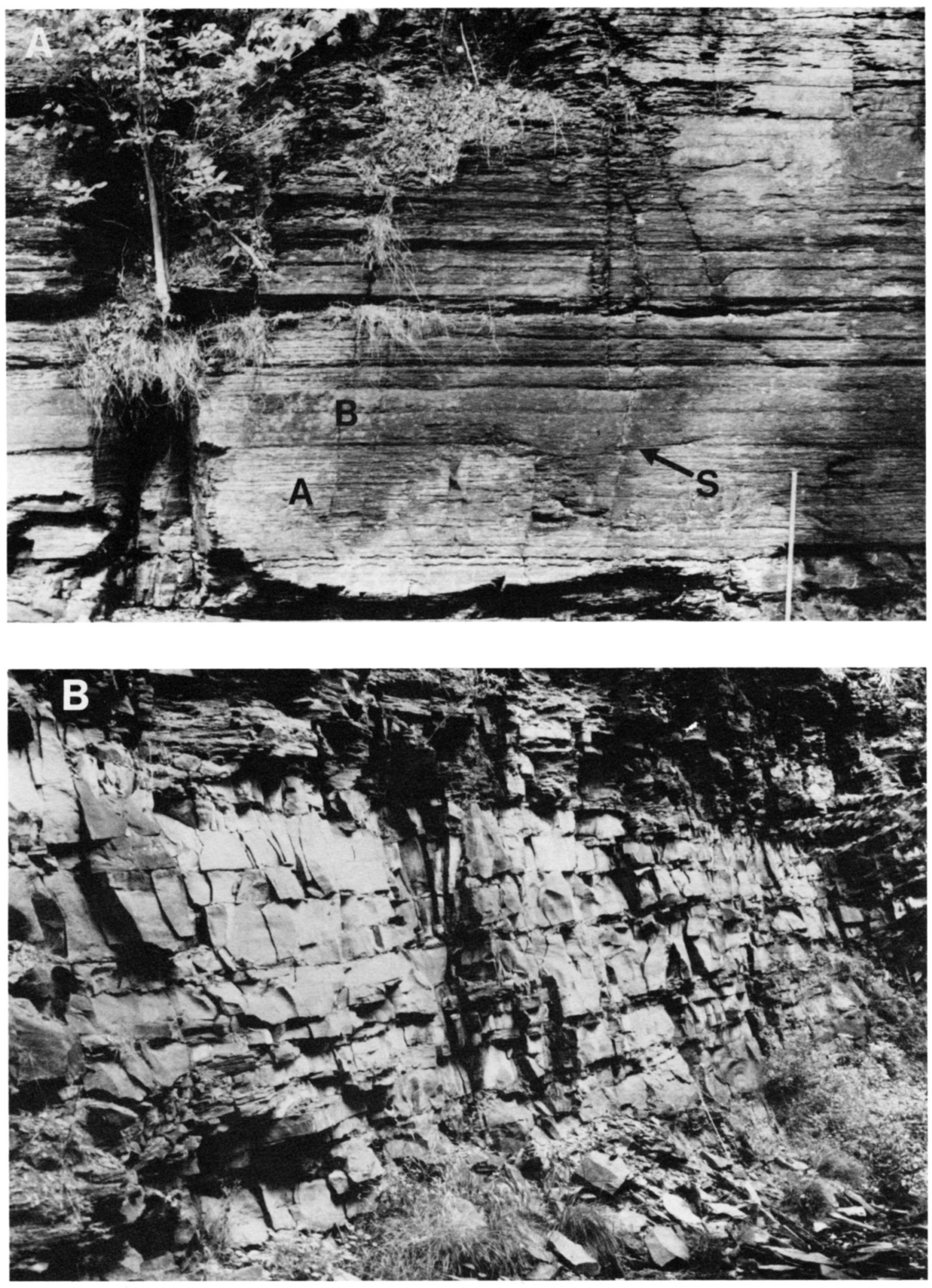

Fig. 9. Curry Brook Member. (A) Coarsening-upward unit, passing from clay shale at the base (base of metre stick) to streaked mudstone " $A$ " to alternating mudstone and planar-bedded sandstone "B". Note the planar nature of the bedding contacts, and the small slump "S". The base of the next unit follows the grassy ledge in the middle of the photograph. (B) Planar-bedded sandstone. Measuring stick (base of cliff, at right) is $1.2 \mathrm{~m}$ long. 
sandstone units, and sideritic nodules are important distinguishing characteristics.

Repeated asymmetric, coarsening-upward cycles, 1 to $22 \mathrm{~m}$ thick (average $6 \mathrm{~m}$ ), are characteristic of the member (Figs. 10,11A,B) and were described in detail by Martel and Gibling (1991). A complete cycle contains four facies. Facies 1 consists of dark grey, fossiliferous and fissile clay shale with minor siltstone lenses. Facies 2 is composed of siltstones and very fine grained sandstones interbedded with clay shale. Subaerial and shallow water features are common and generally increase upward. Lensoid, scour-based bodies of very fine sandstone and siltstone form the lowermost strata and contain hummocky cross-stratification (HCS), planar lamination and wave ripples. Sole structures, including

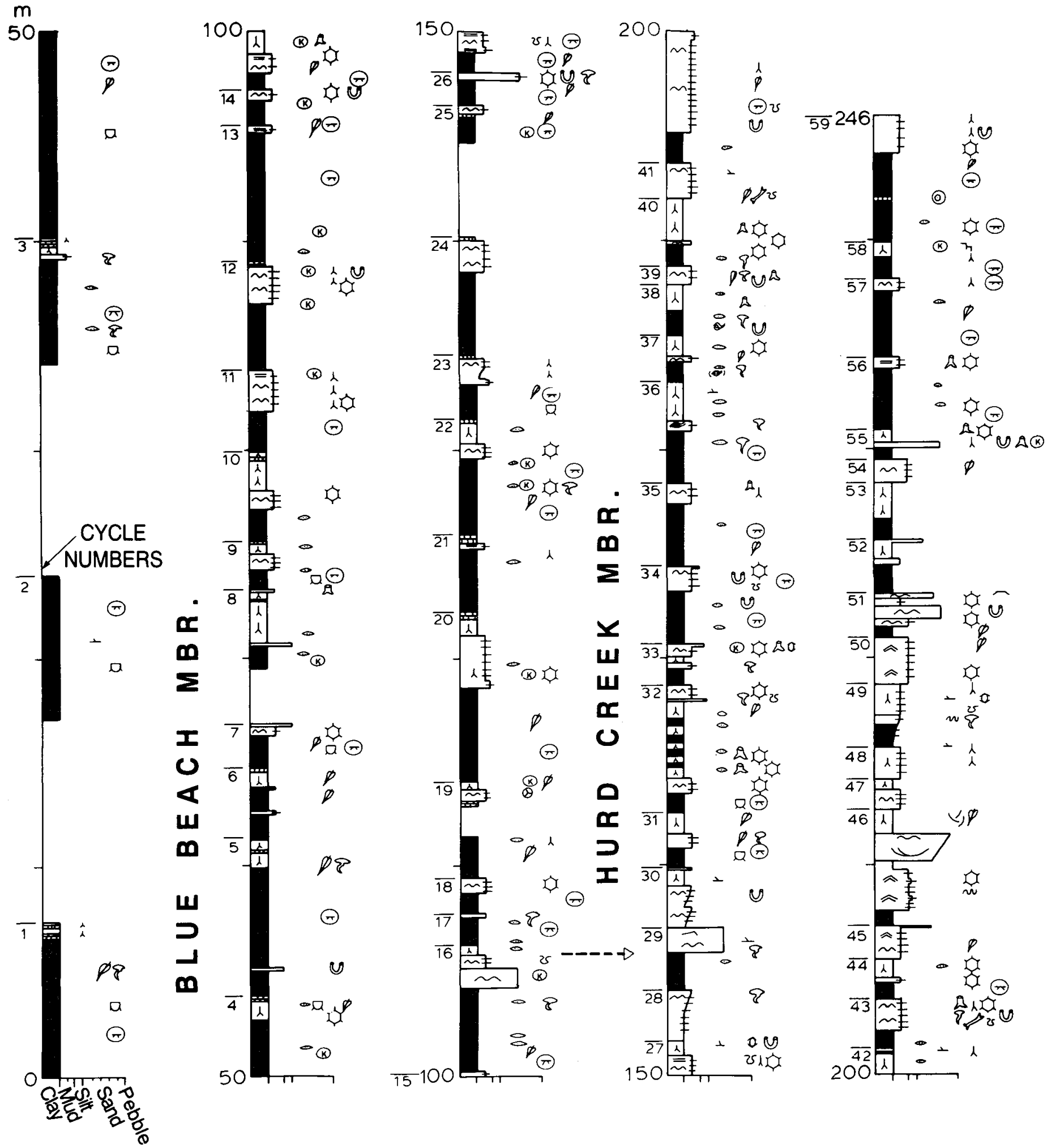

Fig. 10. Lithologic log of the Blue Beach section. See Figure 5 for location and Figure 6 for legend. 

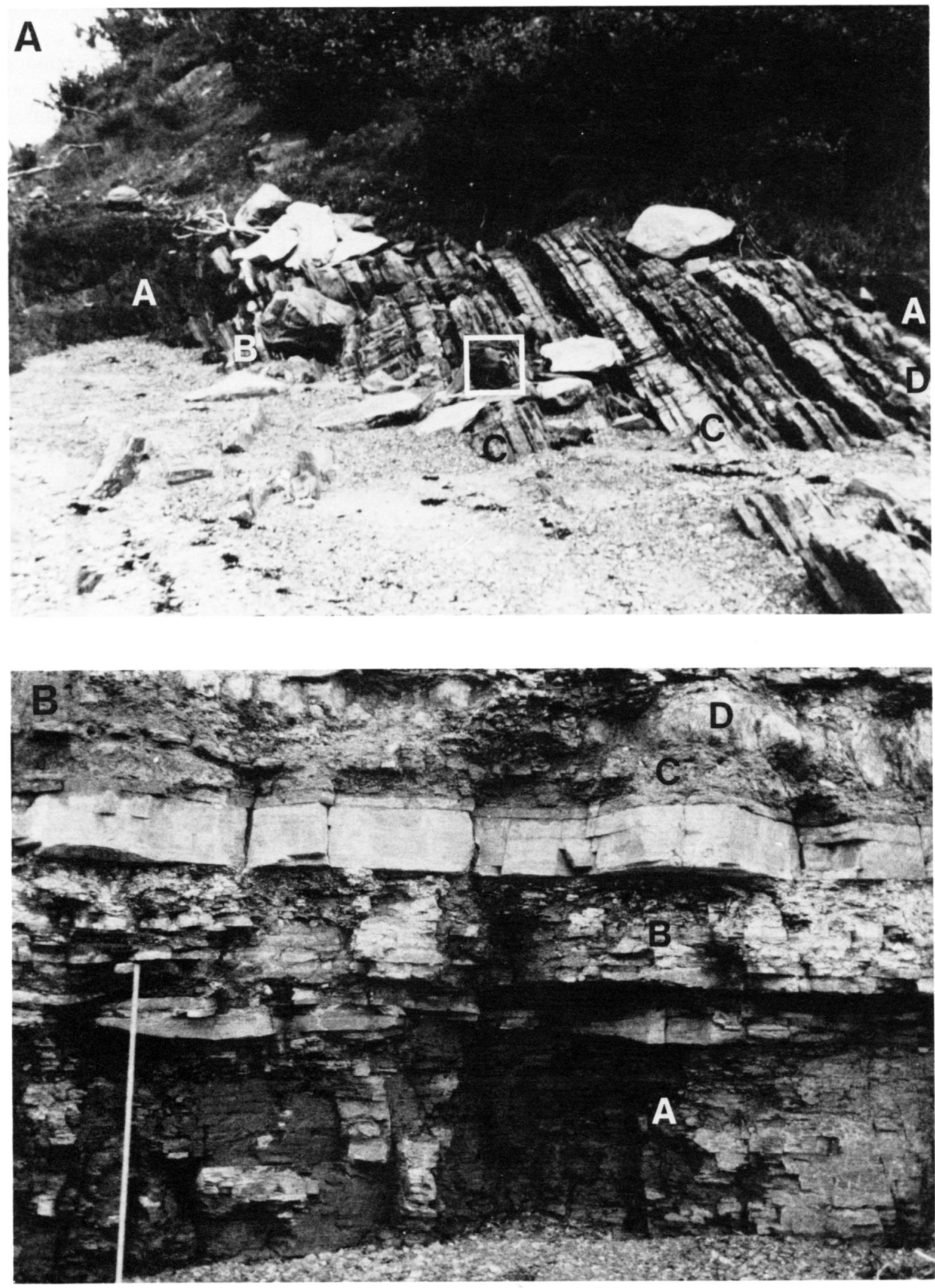

Fig. 11. Blue Beach Member. (A) Coarsening-upward cycle (younging to the right) at Tennycape. Cycle comprises: clay shale " $A$ "; wave-rippled sandstone "B"; tabular, continuous siltstone bedsets "C" separated by clay shale bedsets; duricrust " $D$ " at the cycle top. Knapsack (outlined) is $40 \mathrm{~cm}$ high. (B) Coarsening-upward cycle at Blue Beach. Cycle comprises: clay shale " $A$ "; siltstone and sandstone interbedded with clay shale " $B$ "; disrupted green mudstone " $C$ "; and carbonate duricrust " $D$ ". Visible portion of scale is $90 \mathrm{~cm}$ long. (C) Casts of in situ tree trunks preserved in a siltstone layer. Fractures are structural (as opposed to desiccation) cracks. Hammer is $31 \mathrm{~cm}$ long. 


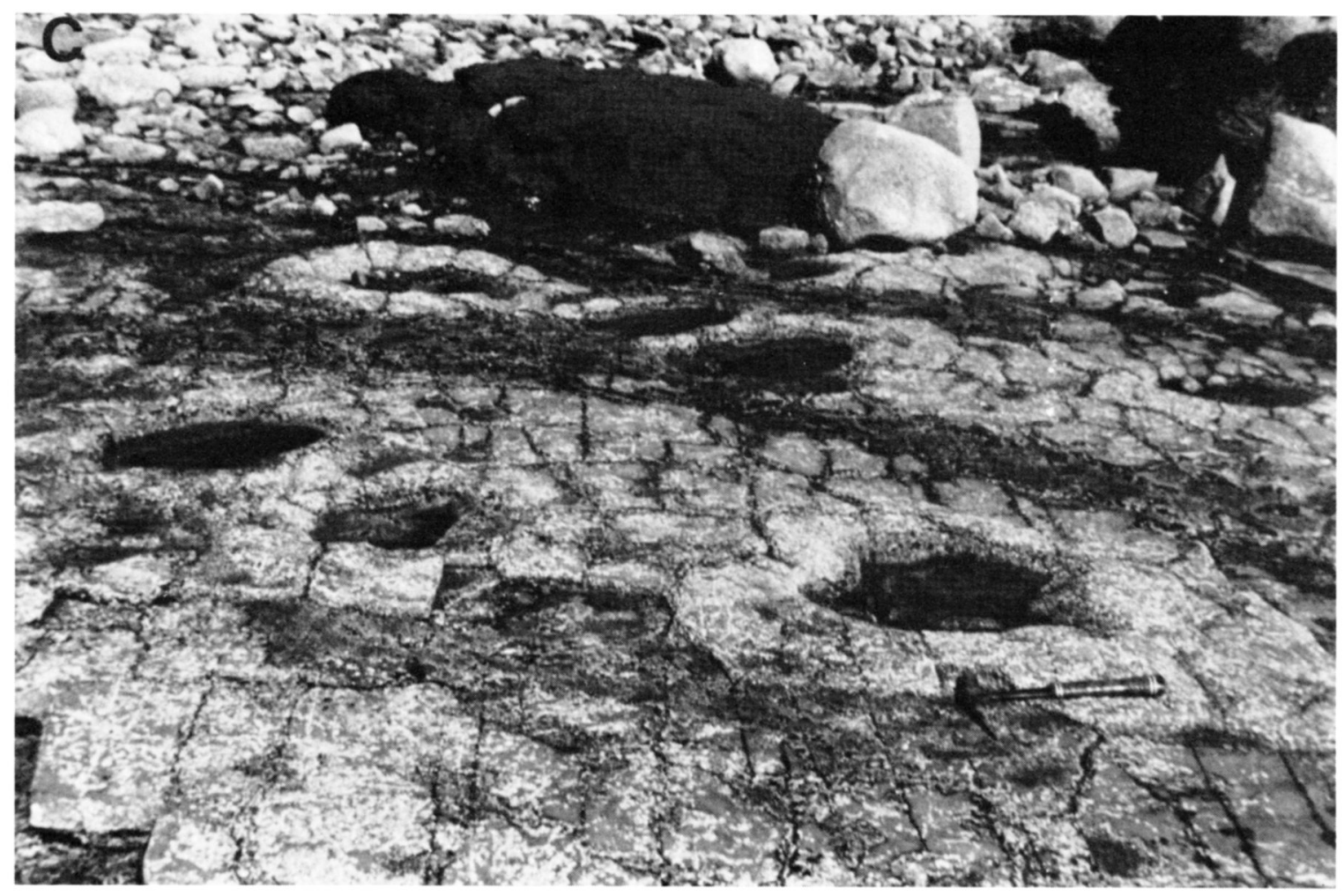

Fig. 11 Continued.

recurved groove casts (Martel and Gibling, 1994) and clastic dykes (Martel and Gibling, 1993), are common in these strata. Wave-rippled, very fine- to fine-grained sandstone, in bedsets 5 to $20 \mathrm{~cm}$ thick, typically overlies the HCS-bearing strata. Planar-bedded siltstone caps most occurrences of this facies. Facies 3 consists of severely disrupted, olive grey to green mudstone, in many cases interbedded with tabularbedded siltstone. Facies 4 consists of massive, laterally continuous, tabular dolomite, and nodular dolomite within disrupted mudstones. Vertical trees are preserved locally within the topmost two facies (Fig. 11C).

Clay shale samples from the Blue Beach Member of the Blue Beach section have recently yielded agglutinated foraminifera and ostracodes with hypersaline and fresh water affinities (N. Tibert, oral communication, 1995).

\section{Depositional Environment}

The Blue Beach Member was inferred by Martel and Gibling (1991) to have been deposited in a large, wave-dominated lake. The cycles are progradational in style and represent an upward transition from offshore clay shales (facies 1) to nearshore/shoreline sandstones and siltstones (facies 2) to hydromorphic paleosols (facies 3 and 4). The grey clay shale facies was deposited mainly below wave base. Deep waters were probably oxygenated, allowing scavengers to survive, but the fissile nature of the shales suggests that interstitial waters were anaerobic or dysaerobic (Ekdale and Mason, 1988). The presence of wave ripples, HCS and recurved groove casts in facies 2 indicates that wave action was prominent in shallow-water parts of the cycles. The discovery of agglutinated foraminifera and ostracodes now suggests that the water body was, at least periodically, connected to the ocean and experienced restricted-marine conditions (cf. Wightman et al., 1994). The salinity tolerances of other faunal elements are uncertain at present.

\section{Hurd Creek Member}

\section{Lithology}

The Hurd Creek Member contains two types of cycle: coarsening-upward, sandstone-dominated cycles and clay shale/ siltstone-dominated cycles. The sandstone-dominated cycles are up to $16 \mathrm{~m}$ thick and consist of a basal clay shale overlain by one or a combination of: (A) planar- and lenticularbedded siltstone and clay shale (Figs. 12, 13A); (B) flaserbedded sandstone; and (C) interbedded rippled sandstone and clay shale. These lithofacies are in turn overlain by coarsening-upward, medium- to very coarse-grained sandstone with planar and trough cross-stratification in sets up to 25 $\mathrm{cm}$ thick (Fig. 13B); the sandstones are up to $8.5 \mathrm{~m}$ thick and commonly laterally continuous. The sandstones are generally well-sorted, quartzose, with varying proportions of intraclasts of paleosol nodules, oolitic limestone and mudstone.

The coarsening-upward clay shale/siltstone cycles resemble the cycles of the Blue Beach Member. They make up a small proportion of the Hurd Creek type section (Fig. 12), but are common or even predominant in other sections (Fig. 10).

\section{Depositional Environment}

The Hurd Creek Member was deposited within a large, wave-influenced standing body of water. The coarseningupward cycles indicate repeated progradation of coastal sedi- 


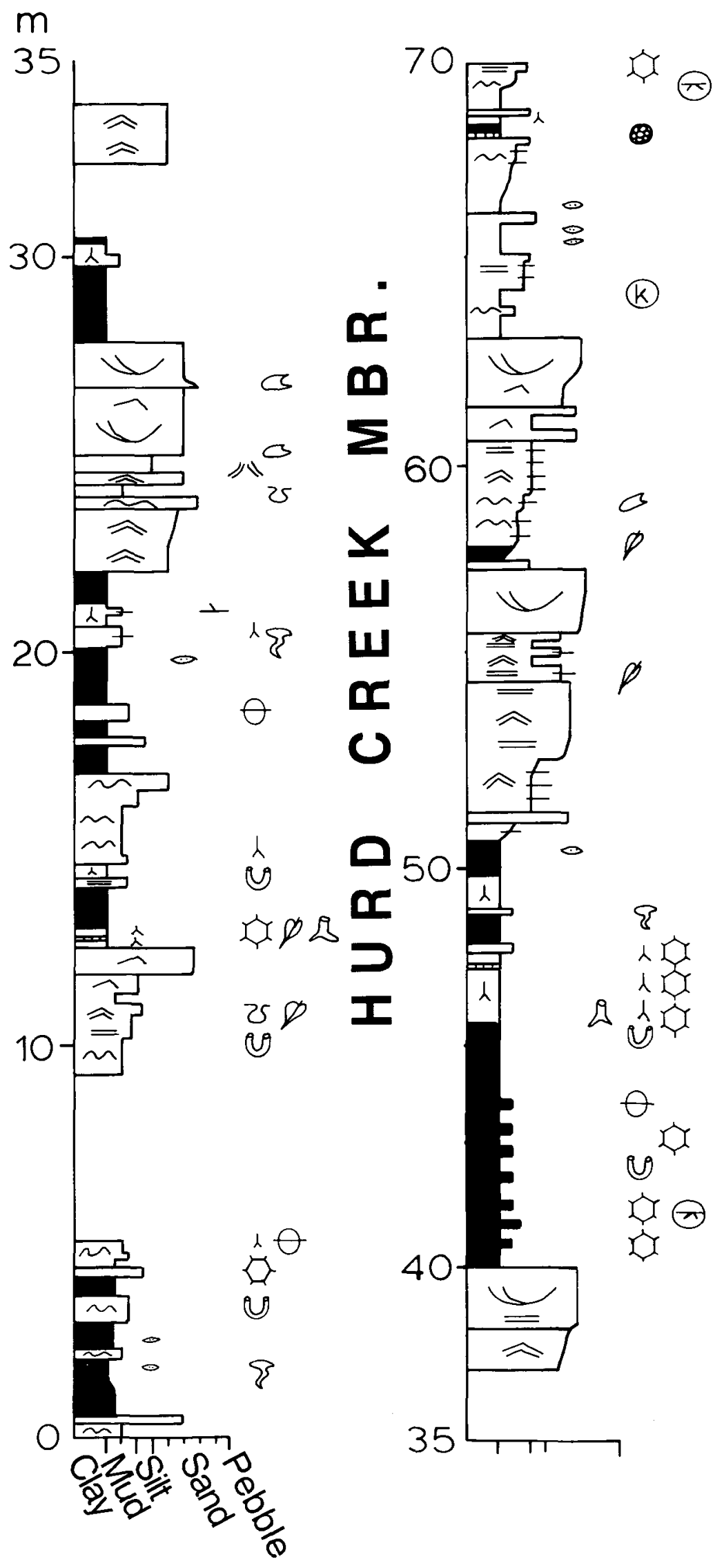

Fig. 12. Lithologic log of the Hurd Creek section. See Figure 5 for location and Figure 6 for legend. 

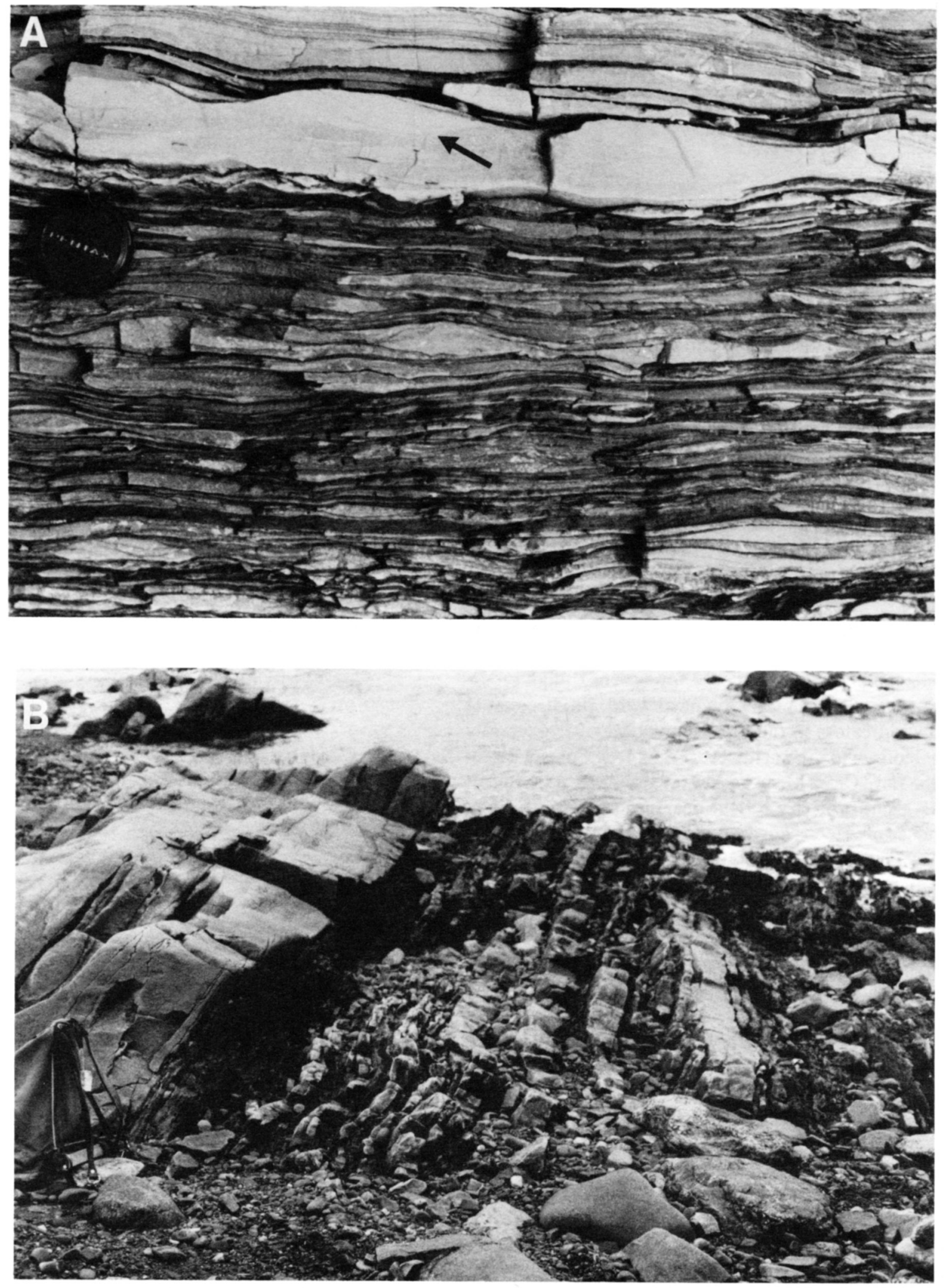

Fig. 13. Hurd Creek Member. (A) Lenticular-bedded siltstone and clay shale. A sandstone unit shows wave-ripple lamination (arrowed) with systematic dip of foresets towards the right, and probably represents storm deposition. Lens cap is $5 \mathrm{~cm}$ in diameter. (B) Coarsening-upward, sandstone-dominated cycle beginning with shale on the right, overlain by interbedded sandstone and clay shale, and then erosively overlain by cross-bedded sandstone. Knapsack (at left) is $40 \mathrm{~cm}$ high. 
ments over offshore sediments, as for those of the Blue Beach Member. However, the cross-bedded sandstones that cap many cycles are interpreted as shoreline attached, sand bar deposits. Some sandstones with deeply erosional bases and moderate sorting may represent deltaic distributary-channel deposits, broadly similar to those of the Curry Brook Member.

\section{Cheverie Formation}

The Cheverie Formation is a coarse grained alluvial deposit, about $100 \mathrm{~m}$ thick in the Avon River area, with coarse grained, meandering channel deposits and red floodplain paleosols, including calcretes (Moore, 1985; Conrod, 1987). Despite the presence of disconformable and perhaps unconformable contacts with the underlying Horton Bluff Formation (Moore, 1995), the lower portion of the Cheverie contains the same upper Tournaisian spore assemblage (Spelaeotriletes cabotii) as the Hurd Creek Member (Fig. 3) (Utting et al., 1989). This indicates a relatively short time interval between the two deposits and perhaps syntectonic movements during deposition of the Horton Group.

\section{Paleoflow patterns}

Paleoflow indicators were difficult to measure in the Harding Brook Member due to the sparsity of three-dimensional exposure. Partially exposed foresets of trough crossbeds in interval (C) generally dip northward. Unidirectional paleoflow indicators in the Curry Brook Member generally shows paleoflow to the northwest (Fig. 14A). Foreset directions of the Hurd Creek Member show migration to the northeast (Fig. 14B), but probably reflect nearshore transport under the influence of waves. Paleoflow patterns for the Blue Beach Member were discussed by Martel and Gibling (1991, 1993, 1994); unidirectional indicators are scarce, and wave-ripple crests at Tennycape and Blue Beach are generally oriented north-south to northwest-southeast. The Cheverie Formation near Hantsport shows paleoflow to the northwest (Conrod, 1987).

\section{Horton Group tectonic history in THE Windsor Subbasin}

The Horton Group strata in the Minas Basin area have geotectonic importance because they are the lowermost units of the Paleozoic to overstep the Acadian Orogen. They rest upon rocks of both the Meguma and Avalon terranes, which were brought into juxtaposition during the Acadian Orogeny. The terranes are inferred to have been in close proximity by the Early to Middle Devonian, based on shallow water conditions and continental plant remains in the Torbrook Formation of northwestern Nova Scotia (Schenk, 1991). Subduction during terrane accretion is inferred from deepcrustal seismic data from the Bay of Fundy (Keen et al., 1991) and from geochemical data from igneous rocks in the Meguma Terrane (Tate and Clarke, 1993).

The Late Devonian miospore age for the basal Harding
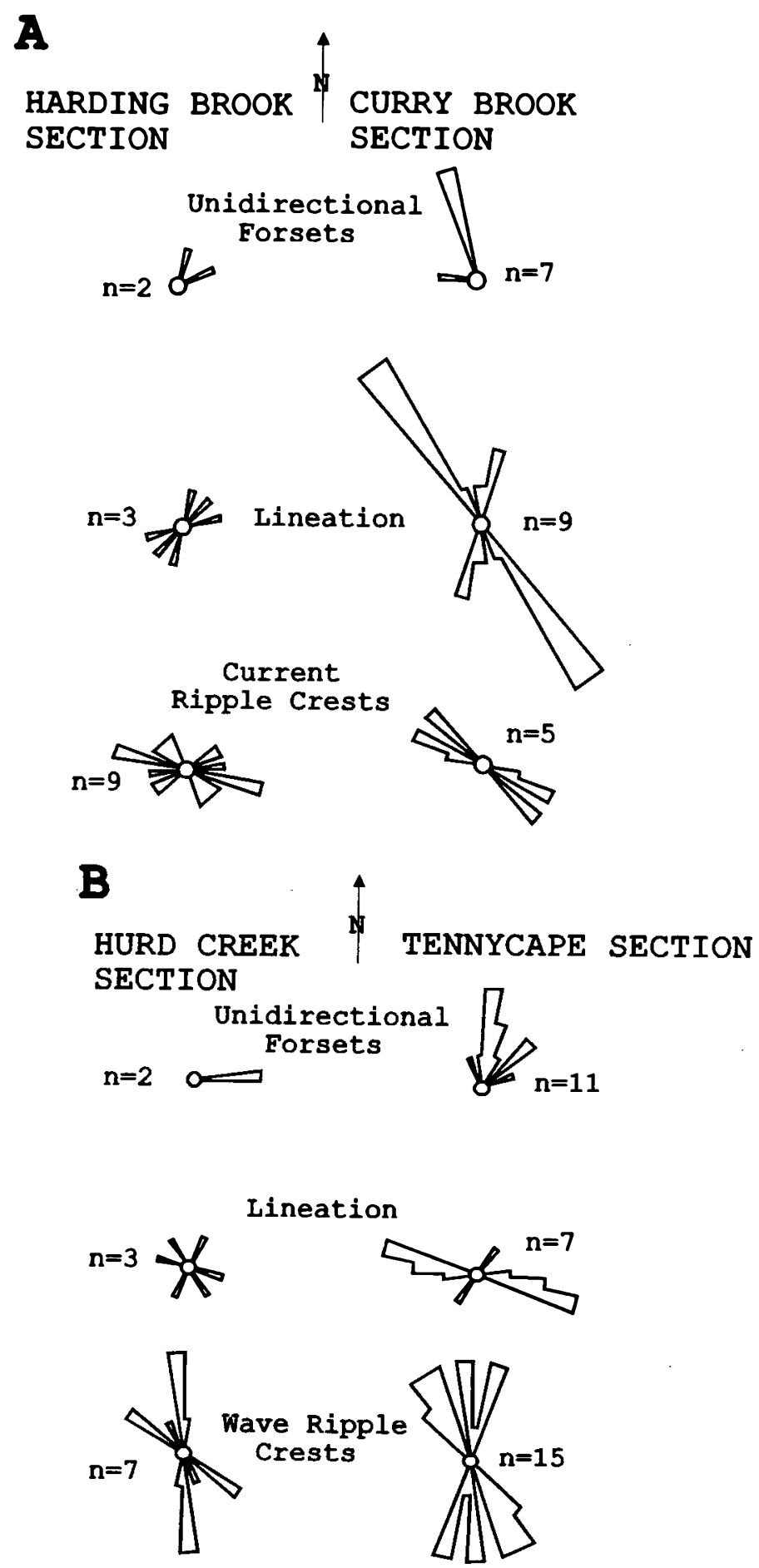

Fig. 14. Paleoflow data for the Curry Brook Member (A) and the Hurd Creek Member (B). In (A), unidirectional readings are from rib-and-furrow structures (Curry Brook section) and trough cross-beds (Harding Brook section); current lineation and current-ripple crests (bipolar data) also represent unidirectional flow. In (B), unidirectional readings are from flute casts (Hurd Creek section) and trough cross-beds (Tennycape section); lineation readings are from current lineation, scour axes and groove casts; ripple crests are from both current- and wave-generated ripples. " $n$ " denotes number of measurements.

Brook strata in the type area provides an upper age limit for terrane accretion. The age of the Devonian-Carboniferous boundary was estimated at $363 \mathrm{Ma}$ by Harland et al. (1989). 
However, Claoue-Long et al. (1992) used volcanic horizons at an auxiliary stratotype in Germany to date the boundary at $353.2( \pm 4) \mathrm{Ma}$. Based on this more recent age assessment, the age of the basal Harding Brook strata may be about $355 \mathrm{Ma}$.

The Horton Bluff Formation locally rests nonconformably on granitic rocks of the South Mountain Batholith, which were intruded into the Meguma Group during a late phase of the Acadian Orogeny. Granitic rocks in the outcrop belt south of the study area are dated at about $370 \mathrm{Ma}$ (Clarke et al., 1993), Late Devonian according to Harland et al. (1989). Thus age relations of rocks in the area imply that parts of the South Mountain Batholith were exhumed and eroded within about $15 \mathrm{Ma}$ after intrusion. Petrographic evidence from plutons at various locations within the batholith (Ham, 1988), and specifically south of the Horton type area (Jamieson, 1974), suggests emplacement at about 10 to $15 \mathrm{~km}$ depth. Both Hill (1991) and Kontak and Reynolds (1994) document rapid uplift and cooling of Meguma Terrane rocks through a period of ca. $10 \mathrm{Ma}$ following the emplacement of (ca. $370 \mathrm{Ma}$ granitic suites. Hence, the batholith and host metasedimentary rocks of the Meguma Terrane in the Horton type area were exhumed rapidly, at (very approximately) a rate of about $1 \mathrm{~mm}$ per year, in the latest stages of the Acadian Orogeny and prior to renewed extension and Horton Group sedimentation. Rough calculations indicate that such an exhumation would generate between 20,000 and $30,000 \mathrm{cu}-$ bic $\mathrm{km}$ of sediment during the early to middle Devonian from the onshore Meguma Terrane alone.

The Blue Beach Member and its component cycles thicken northward and exhibit an increased proportion of offshore facies from Blue Beach to Tennycape, towards the Cobequid Fault. This led Martel and Gibling (1991) to postulate that the Horton Bluff Formation in the type area was laid down in a half-graben controlled by the Cobequid Fault or a precursor fault system, resulting in an enhanced rate of subsidence on the south side of the fault. Paleoflow patterns in the Horton Bluff Formation in the type area indicate that fluvial systems entered the Windsor Subbasin from the south. These paleocurrents and the granitic and Meguma Group derived clasts indicates that the Meguma Terrane was supplying sediment to the subbasin at that time. Evidence for syndepositional extension along the Cobequid Fault during the Late Devonian-Early Carboniferous was provided from stratigraphic analysis by Mooney (1987), and from age dating of plutons in the Cobequid Hills by Pe-Piper et al. (1989). The Nuttby and Rapid Brook formations in the Cobequid Hills north of the Cobequid Fault include coarse conglomerates and may be coeval with the Horton Bluff Formation. A half graben subsiding along the Cobequid Fault would be expected to show coarse conglomerates of limited areal extent over the footwall, and finer grained sediments over the larger, gently dipping hanging wall (Frostick and Reid, 1987; Hamblin and Rust, 1989). The Horton Bluff strata are consistent with the fine grained model of a gently dipping hanging wall. Unfortunately, the complexity of the Cobequid FaultChedabucto Fault Zone and the sediments within means that the sedimentary pattern near the fault is unclear.
Seismic profiles and sedimentary evidence at many localities in Atlantic Canada indicate that Horton Group strata occupy local half grabens with varied polarity, that is, alternating dips of the graben floors along strike (Hamblin and Rust, 1989; Marillier et al., 1989; Sanford and Grant, 1990; Durling and Marillier, 1993). Local "sag" basins and thin veneers of Horton strata were also identified on seismic profiles by Durling and Marillier (1993). Horton Group strata thin and locally pinch out in the southern part of the type area, but a veneer could have covered parts of the Meguma Terrane. Strata coeval with the Horton Group in the Deer Lake Basin, Newfoundland, show evidence for dextral strike-slip along the Cabot Fault Zone during the Tournaisian (Hyde et al., 1988). Late Devonian to Tournaisian rift and halfgraben development, following phases of the Caledonian and Ellesmerian orogenies, is recognised elsewhere in Europe and North America, for example, in northern England (Fraser and Gawthorpe, 1990), northern Greenland, and Svalbard (Stemmerik and Worsley, 1989).

The Horton Group shows a tripartite stratigraphic pattern within at least eight subbasins of the Maritimes Basin that have been studied (Fig. 15). A similar tripartite pattern also occurs within the Deer Lake (Hyde et al., 1988), and Sackville (Martel, 1987) subbasins (Fig. 1), but these areas are not represented in Figure 15 due to a lack of palynological data. The tripartite pattern typically comprises: (1) a basal thick, coarse grained alluvial succession (commonly red and/or green) that rests unconformably on basement rocks; (2) a dark grey, fine grained lacustrine succession; and (3) an upper coarse- to fine-grained alluvial succession (commonly red and/or green). Within the Windsor Subbasin, these stages are represented by: (1) the fluvial Harding Brook Member, (2) the lacustrine to fluvio-lacustrine Curry Brook, Blue Beach and Hurd Creek members, with marine influence possible in the Blue Beach Member, and (3) the fluvial Cheverie Formation (Fig. 16). Conglomeratic sequences form the basal strata of the Horton Group and equivalent units in several subbasins (Belt, 1968a, 1968b; Giles and Boehner, 1982; Knight, 1983; Pickerill et al., 1985; Hamblin and Rust, 1989) and are generally much thicker than the equivalent Harding Brook Member of the Windsor Subbasin.

Palynological dating indicates that the dark shale (stage 2) is of middle to late Tournaisian age across the Maritimes Basin (Fig. 15). The correlation between rapid or maximum subsidence rates and lacustrine deposition has long been recognized (Li Sitian et al., 1984; Blair, 1987; Blair and Bilodeau, 1988). These models predict that periods of active subsidence cause a rise in relative base-level, promoting lacustrine or marine deposition, and restricting alluvial wedges to the basin margin. During periods of reduced subsidence rates, alluvial strata prograde out across the basin. A number of authors have interpreted the Horton Group lacustrine deposits throughout the Maritimes Basin as resulting from a period of near-synchronous rapid tectonic subsidence (Martel, 1987, 1990; Martel and Gibling, 1988; Hamblin and Rust, 1989; Hamblin, 1992).

More important than the subsidence rate, however, is the relationship between the sediment flux into the basin 


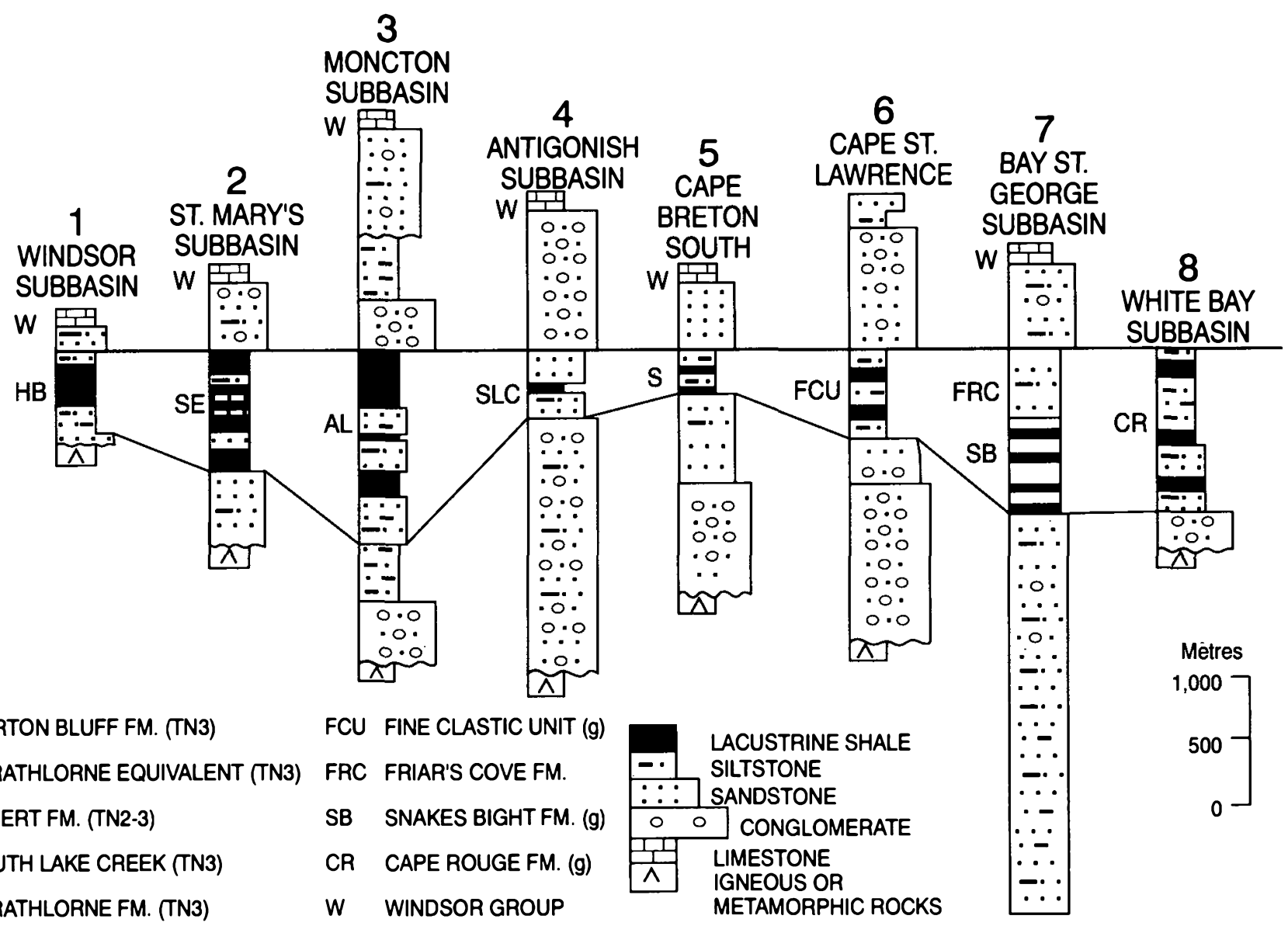

Fig. 15. Regional stratigraphy of the Horton Group and stratigraphic equivalents within the Maritimes Basin. The lacustrine shales are correlated using spore-based divisions and data ( $\mathrm{Tn}_{2}$ and $\mathrm{Tn}_{3}$, or middle to late Tournaisian) from Utting (1987), Utting et al. (1989), Utting and Hamblin (1991) and Martel et al. (1993). Spore zone "g" (Hacquebard, 1972) is attributed to the Tournaisian stage and is equivalent to the spore-based divisions $\left(\mathrm{Tn}_{2}\right.$ and $\mathrm{Tn}_{3}$ ). Stratigraphic columns are modified after Hacquebard (1972), Knight (1983), Prime (1987), Utting (1987) and Utting et al. (1989). The datum is located at the top and the correlation line at the base of the lacustrine shale unit. See Figure 1 for locations.

and the generation of accommodation space (Galloway, 1991), mainly through subsidence. Substantial lacustrine environments only occur where the basin accommodation space has outpaced sediment flux. Where this happens, the basin is underfilled, and fine grained sediment is trapped within the basin. If the basin is hydrologically open (lakes with an excess of water), the dissolved component will be flushed from the basin. If the basin is hydrologically closed as in an internally drained playa lake setting, however, this dissolved fraction will be concentrated within the basin and may eventually form chemical deposits such as limestones and evaporites. Sediment flux may eventually overcome creation of accommodation space, either through increased sediment flux or decreased accommodation. This produces a dramatic change in the basin sediment character. A fluvial system is established across the entire basin, and much of the fine grained and dissolved material is bypassed through the basin, leaving a concentration of the coarser materials.

The interpretation of the Horton Group in the Windsor Subbasin is shown in Figure 16. The diagram shows a positive gradient, where water flows through the basin under the drive of gravity (both erosional and fluvial stages), and a negative gradient, where water is ponded within the basin in a lake or playa. Initially in the Windsor Subbasin, rivers flowed through the area removing all sediment $(E)$, producing an unconformity. Subsidence increased until fluvial sediments began to be preserved $(F)$. Subsidence eventually outstripped sediment input and depressions formed $(F / L$ : negative gradient), waters were ponded, and fine grained sediments were trapped within lakes or restricted-marine bays (L). As subsidence rates slowed, the depressions were infilled $(F / L)$ and flow-through fluvial systems (F) were re-established. Alluvial-fan activity is known to have been restricted to the basin margin in several other subbasins during periods of lacustrine deposition (Murray, 1960; Belt, 1968a; Pickerill et al., 1985; Carter and Pickerill, 1985; Hamblin and Rust, 1989).

Since most of the Maritimes subbasins had Tournaisian lacustrine deposits, water input into the basins appears to have been greater than evaporation during this time. This favours (but does not necessitate) a "humid" climate. However, toward the end of the Maritimes Basin Horton deposition, the climate may have become more arid, as indicated by the increased oxidation of sediments, and playa lake and evaporite deposition in the upper Horton Group of the Moncton Subbasin. The location of the ocean that may have periodi- 


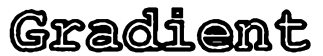

\section{Trezpe Area}

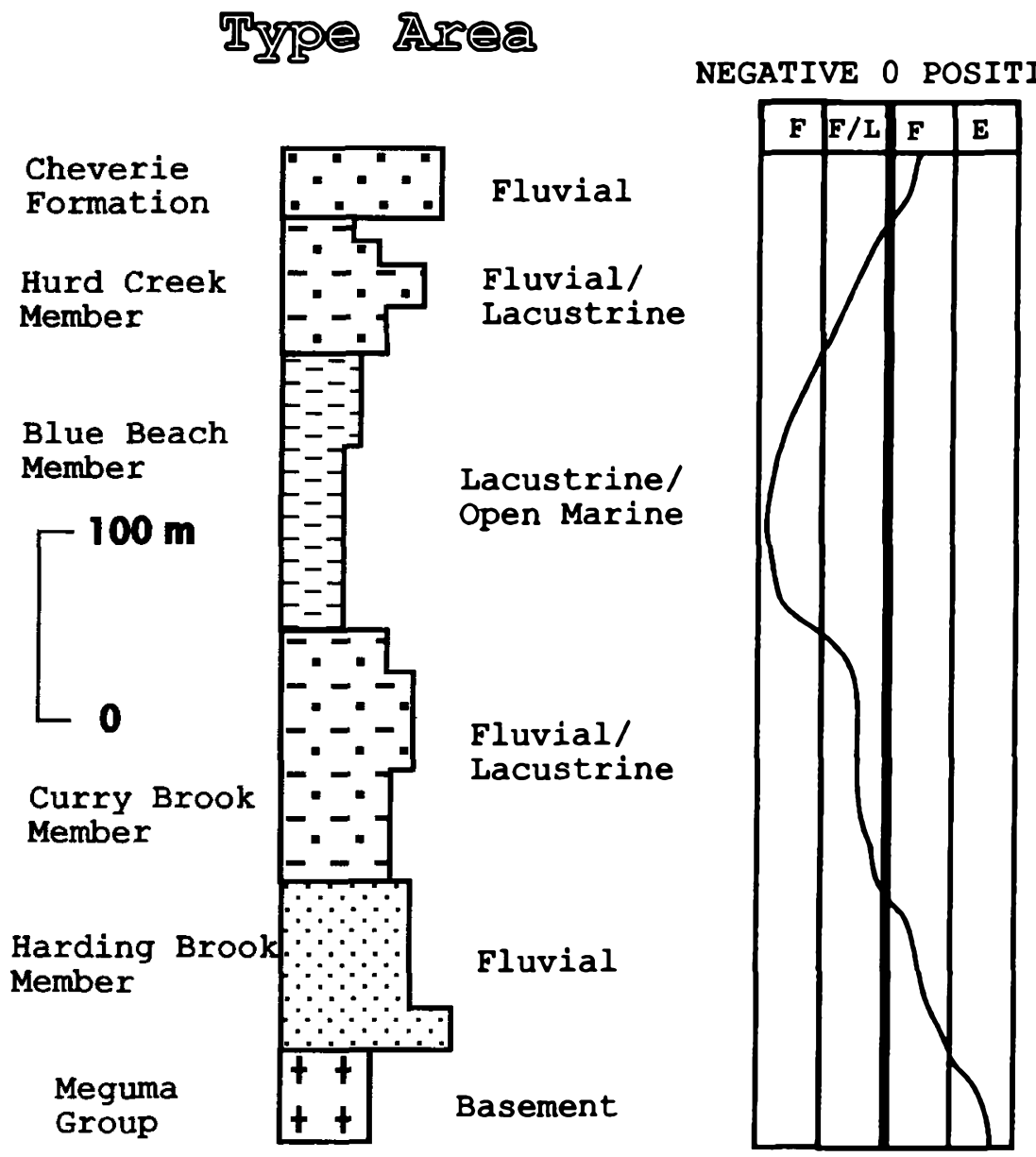

Fig. 16. Simplified stratigraphic column for the Horton Group in the type area, with stage interpretation. Changes in subsidence rates are inferred to have resulted in gradient changes across the basin and an upward change from gravity-driven fluvial systems ( $F$ ) to fluvio-lacustrine conditions (F/L) to relatively deep lakes $(\mathrm{L})$ from the Harding Brook to the Blue Beach Member. Erosion (E) occurs above an "equilibrium" gradient. Some lacustrine parts of the succession may have been subject to marine influence.

cally influenced the Windsor Subbasin during deposition of the Blue Beach Member is uncertain: coeval marine deposits are widely distributed in Europe and North America (e.g., Haszeldine, 1984). The basal Macumber Formation of the overlying Windsor Group represents a subsequent, widespread marine inundation.

Recognition of a synchronous phase of subsidence in many of these local subbasins (Martel and Gibling, 1988; Utting et al., 1989) implies that their development and filling was governed, at least in part, by regional tectonic processes/events on a larger scale than the small, component depocentres. The local faults that bound the subbasins may have been components of one or more master faults at deeper crustal levels: Marillier et al. (1989) noted that a reflector at mid-crustal depths below the Sydney Basin may have been related to Horton Group half grabens at a higher structural level.

Deformation of Horton strata probably commenced locally near the end of Horton Group deposition (Durling and Marillier, 1993; St. Peter, 1993). Intense deformation of the Horton Bluff Formation in the Windsor Subbasin may have been related in part to a thrusting event, involving the Meguma and Avalon terranes, that has been documented in the western Cobequid Hills and dated provisionally at $328 \mathrm{Ma}$ (Namurian) (Waldron et al., 1989). Middle Carboniferous tectonic events have been documented throughout much of the Maritimes Basin, and have been referred to as the "Maritime Disturbance" (Poole, 1967) or attributed to the Alleghenian Orogeny (Rast, 1984). Dextral movement along the CobequidChedabucto Fault caused substantial early Westphalian deformation (Plint and Van de Poll, 1984; Nance, 1987) and probably affected the Horton Group in the Windsor Subbasin. Sinistral movement along the Cobequid-Chedabucto Fault during Mesozoic rifting is associated with a regional unconformity that eroded the rift-edge Horton Group and younger sediments, placing the Triassic unconformably on the Horton.

\section{Conclusions}

(1) The Devonian-Carboniferous Horton Group in the type area near Hantsport, Nova Scotia, is at least $525 \mathrm{~m}$ thick, and four members are formally defined here. The basal Harding Brook Member (latest Devonian to Tournaisian) is 
a braided-fluvial sandstone and conglomerate unit, with minor shales, that rests unconformably on rocks of the Meguma Terrane. The Curry Brook, Blue Beach and Hurd Creek members, all Tournaisian, contain substantial thicknesses of dark shale and were deposited under fluvio-lacustrine, lacustrine and fluvio-lacustrine conditions, respectively. Periodic marine incursions are postulated from microfossil data for the Blue Beach Member. The alluvial Cheverie Formation, of Tournaisian age, is about $100 \mathrm{~m}$ thick.

(2) The sequence of these strata can be interpreted as the result of interplay between sediment flux, accommodation space and climate. Fluvial deposits, the Harding Brook Member and Cheverie Formation, were widespread where there was overfilling and continuous gravity-driven streams crossed the basin. When the basin was underfilled (accommodation space greater than sediment influx), fine-grained sediments were trapped within the basin as waters were ponded by depressions (Curry Brook, Blue Beach and Hurd Creek formations). Periodic incursions of marine waters may have occurred within the Blue Beach Member. Otherwise, it appears that the basin was hydrologically open during the remainder of Horton Bluff deposition, indicating that water input from the drainage area was greater than evaporation.

(3) The Horton Bluff Formation was laid down in a halfgraben bounded to the north by the Cobequid Fault or a precursor. Northward paleoflow for the alluvial deposits indicates that rivers flowed across the Meguma Terrane into the southern part of the depocentre. This indicates that at least part of the Meguma Terrane was shedding sediment into the basin.

(4) Following Acadian deformation and intrusion of the South Mountain Batholith (ca. $370 \mathrm{Ma}$ ), approximately 10 km of Meguma Terrane was exhumed over a period of about 15 Ma prior to Horton Group sedimentation in the type area. This generated a large volume of Devonian sediment, the location of which is presently unknown.

(5) Lacustrine and/or marine shales, coeval middle to late Tournaisian) with those of the Blue Beach and Hurd Creek members, are widely distributed in extensional basins across Atlantic Canada. This indicates a regional phase of relatively rapid subsidence during which base-level rose and alluvial deposits were confined to basin margins. The synchronous nature of this phase suggests that faults bounding the local basins were linked to a regional-scale detachment.

\section{ACKNOWLedgements}

This paper results from the Ph.D. thesis of ATM, supported by a Natural Sciences and Engineering Research Council of Canada Scholarship at Dalhousie University, and was written during tenure of a North Atlantic Treaty Organization PostDoctoral Fellowship at Oxford University, United Kingdom. Additional support came from a Natural Sciences and Engineering Research Council Research Grant to MRG. We thank Peter Bang for field assistance, and R. Boyd, J. Calder, F. Hein, R. Naylor, R. Ryan, P. Schenk, J. Utting and J. Waldron for helpful discussion. We thank Saarberg Interplan Can Limited for permission to refer to drill core and logs.
Bell, W.A. 1929. Horton-Windsor district, Nova Scotia. Geological Survey of Canada, Memoir 155.

...- 1960. Mississippian Horton Group of type Windsor-Horton district, Nova Scotia. Geological Survey of Canada, Memoir 314.

Belt, E.S. 1968a. Carboniferous continental sedimentation, Atlantic Provinces, Canada. In Symposium on Continental Sedimentation. Edited by G.deV. Klein. Geological Society of America, Special Paper 106, pp. 127-176.

---- 1968b. Post-Acadian rifts and related facies, eastern Canada. In Studies in Appalachian Geology, pp. Northern and Maritime. Edited by E.-An Zen, W.S. White, J.B. Hadley and J.B. Thompson, Jr. John Wiley, New York, pp. 95-116.

....- 1969. Newfoundland and Carboniferous stratigraphy and its relation to the Maritimes and Ireland. In North Atlantic Geology and Continental Drift. Edited by M. Kay. American Association of Petroleum Geology, Memoir 12, pp. 734753.

BLAIR, T.C. 1987. Tectonic and hydrologic controls on cyclic alluvial fan, fluvial, and lacustrine rift-basin sedimentation, Jurassic-Lowermost Cretaceous Todos Santos Formation, Chiapas, Mexico. Journal of Sedimentary Petrology, 57, pp. 845-862.

Blair, T.C. and Bilodeau, W.L. 1988. Development of tectonic cyclothems in rift, pull-apart, and foreland basins: Sedimentary response to episodic tectonism. Geology, 16, pp. 517-520.

Cant, D.J. and Walker, R.G. 1978. Fluvial processes and facies sequences in the sandy braided South Saskatchewan River, Canada. Sedimentology, 25, pp. 625-648.

CARTER, D.C. and Pickerill, R.K. 1985. Lithostratigraphy of the late Devonian - early Carboniferous Horton Group of the Moncton Subbasin, southern New Brunswick. Maritime Sediments and Atlantic Geology, 21, pp. 11-24.

Claoue-Long, J.C., Jones, P.J., Roberts, J., and Maxwell, S. 1992. The numerical age of the Devonian-Carboniferous boundary. Geological Magazine, 129, pp. 281-291.

Clarke, D.B., MacDonald, M.A., Reynolds, P.H., and Longstaffe, F.J. 1993. Leucogranites from the eastern part of the South Mountain Batholith, Nova Scotia. Journal of Petrology, 34, pp. 653-679.

Clayton, G. 1985. Dinantian miospores and inter-continental correlation. Compte Rendu du Dixieme Congres International de Stratigraphie et de Geologie du Carbonifere, Madrid 1983, 4, pp. 9-23.

Coleman, J.M., Gagliano, S.M., and Webb, J.E. 1964. Minor sedimentary structures in a prograding distributary. Marine Geology, 1, pp. 240-258.

Conrod, D. 1987. Fluvial sedimentation in the lower member of the Cheverie Formation at Blue Beach, Nova Scotia. Unpublished B.Sc. thesis, Dalhousie University, Halifax, Nova Scotia.

Donohoe, H.V., JR. and Wallace, P.I. 1982. Geology maps of the Cobequid Highlands, Nova Scotia. Nova Scotia Department of Mines and Energy, Maps 82-6, 82-7, 82-8 and 82-9, 1:50,000 scale.

Durling, P. and Marillier, F. 1993. Tectonic setting of Middle Devonian to Lower Carboniferous rocks in the Magdalen Basin. Atlantic Geology, 29, pp. 199-217.

Ekdale, A.A. and Mason, T.R. 1988. Characteristic trace-fossil associations in oxygen-poor sedimentary environments. Geology, 16, pp. 720-723.

Ferguson, S.A. 1983. Geological map of the Hantsport area, Nova Scotia. Nova Scotia Department of Mines and Energy, Map 83-1.

FIELDING, C.R. 1984. Upper delta plain lacustrine and fluviolacustrine 
facies from the Westphalian of the Durham coalfield, NE England. Sedimentology, 31, pp. 547-567.

FrASER, A.J. and GAWTHORPE, R.L. 1990. Tectono-stratigraphic development and hydrocarbon habitat of the Carboniferous in northern England. In Tectonic events responsible for Britain's oil and gas reserves. Edited by R.F.P. Hardman and J. Brooks. Geological Society of London, Special Publication 55, pp. 49-86.

Frostick, L.E. and ReID, I. 1987. Tectonic control of desert sediments in rift basins: ancient and modern. In Desert Sediments: Ancient and Modern. Edited by L.E. Frostick and I. Reid. Geological Society of London, Special Publication 35, pp. 53-68.

GallowaY, W.E. 1991. Sediment accumulation rates in time and space: Paleogene genetic stratigraphic sequences of the northwestern Gulf of Mexico basin. Geology, 19, pp. 986-989.

Giles, P.E. and Boehner, R.C. 1982. Geological map of the Shubenacadie and Musquodoboit basins, central Nova Scotia. Nova Scotia Department of Mines and Energy, Map 82-4.

Hacquebard, P.A. 1972. The Carboniferous of Eastern Canada. Compte Rendu, 7th International Carboniferous Congress, Krefeld, 1971, 1, pp. 69-90.

HaM, L.J. 1988. The mineralogy, petrology, and geochemistry of the Halfway Cove - Queensport Pluton, Nova Scotia, Canada. Unpublished M.Sc. thesis, Dalhousie University, Halifax, Nova Scotia.

Hamblin, A.P. 1992. Half-graben lacustrine sedimentary rocks of the lower Carboniferous Strathlorne Formation, Horton Group, Cape Breton Island, Nova Scotia, Canada. Sedimentology, 39 , pp. 263-284.

Hamblin, A.P. and Rust, B.R. 1989. Tectono-sedimentary analysis of alternate-polarity half graben basin-fill successions: Late Devonian-Early Carboniferous Horton Group, Cape Breton Island, Nova Scotia. Basin Research, 2, pp. 239-255.

Harland, W.B., Armstrong, R.L., Cox, A.V., Craig, L.E., Smith, A.G., and SMith, D.G. 1989. A geologic time scale 1989. Cambridge University Press.

Haszeldine, R.S. 1984. Carboniferous North Atlantic palaeogeography: stratigraphic evidence for rifting, not megashear or subduction. Geological Magazine, 121, pp. 443-463.

HiLl, J.D. 1991. Petrology, tectonic setting and economic potential of Devonian peraluminous granitoid plutons in the Canso and Forest Hill areas, eastern Meguma Terrane, Nova Scotia. Geological Survey of Canada, Bulletin 383.

Hyde, R.S., Miller, H.G., Hiscott, R.N., and Wright, J.A. 1988. Basin architecture and thermal maturation in the strike-slip Deer Lake Basin, Carboniferous of Newfoundland. Basin Research, 1, pp. 85-105.

JACkson, C.T. and Alger, F. 1828. A description of the mineralogy and geology of a part of Nova Scotia. American Journal of Science, 14, pp. 305-330.

---- 1829. A description of the mineralogy and geology of a part of Nova Scotia. American Journal of Science, 15, pp. 132160 and 201-217.

JAMIESON, R.A. 1974. The contact of the South Mountain Batholith near Mount Uniacke, Nova Scotia. Unpublished B.Sc. thesis, Dalhousie University, Halifax, Nova Scotia.

Keen, C.E., Kay, W.A., Keppie, J.D., Marillier, F., Pe-Piper, G., and WALDRON, J.W.F. 1991. Deep seismic reflection data from the Bay of Fundy and Gulf of Maine: tectonic implications for the northern Appalachians. Canadian Journal of Earth Sciences, 28, pp. 1096-1111.

Keppie, J.D., St. Julian, P., Hubert, C., Beland, J., Skidmore, B., FyfFE, L.R., et al. 1983. Times of deformation in the
Canadian Appalachians. In Regional Trends in the Geology of the Appalachian - Caledonian - Hercynian - Mauritanide Orogen. Edited by P.E. Schenk. NATO ASI Series, Series C, 116, pp. 307-314.

KNight, I. 1983. Geology of the Carboniferous Bay St. George subbasin, western Newfoundland. Newfoundland and Labrador Department of Mines and Energy, Memoir 1.

KontaK, D.J. and REYNolDs, P.H. 1994. ${ }^{40} \mathrm{Ar} / 39 \mathrm{Ar}$ dating of metamorphic and igneous rocks of the Liscomb Complex, Meguma Terrane, southern Nova Scotia, Canada. Canadian Journal of Earth Sciences, 31, pp. 1643-1653.

Li Sitian, Li Baofang, Heuang Jiafu, and Li Zhen. 1984. Sedimentation and tectonic evolution of the Late Mesozoic faulted coal basins in north-eastern China. In Sedimentology of Coal and Coal-Bearing Sequences. Edited by R.A. Rahmani and R.M. Flores. International Association of Sedimentologist, Special Publication 7, pp. 387-406.

MacDonald, D.J. 1973. Stratigraphy of the Upper Member of the Horton Bluff Formation in the area of the type section near Hantsport, Nova Scotia. Unpublished M.Sc. thesis, Acadia University, Wolfville, Nova Scotia.

Marillier, F., Keen, C.E., Stockmal, G.S., Quinlan, G., Williams, H., Coleman-Sadd, S.P., and O'Brian, S.J. 1989. Crustal structure and surface zonation of the Canadian Appalachians: implications of deep crustal seismic reflection data. Canadian Journal of Earth Sciences, 26, pp. 305-321.

MarTel, A.T. 1987. Seismic stratigraphy and hydrocarbon potential of the strike-slip Sackville Subbasin, New Brunswick. In Sedimentary Basins and Basin-Forming Mechanisms. Edited by C. Beaumont and A.J. Tankard. Canadian Society of Petroleum Geology, Memoir 12, pp. 319-334.

....- 1990. Stratigraphy, fluviolacustrine sedimentology and cyclicity of the Late Devonian/Early Carboniferous Horton Bluff Formation, Nova Scotia, Canada. Unpublished Ph.D. thesis, Dalhousie University, Halifax, Nova Scotia.

Martel, A.T. and Gibling, M.R. 1988. The Horton Bluff Formation: A tectonically influenced fluvial-lacustrine basin fill. Abstract, 1988 Atlantic Geoscience Society Colloquium.

... 1991. Wave-dominated shoreline facies and tectonically controlled cyclicity of the Lower Carboniferous Horton Bluff Formation, Nova Scotia, Canada. In Lacustrine Facies Analysis. Edited by P. Anadon, L. Cabrera, and K. Kelts. International Association of Sedimentologist, Special Publication 13, pp. 223-243.

.... 1993. Clastic Dykes of the Devono-Carboniferous Horton Bluff Formation, Nova Scotia: storm-related structures in shallow lakes. Sedimentary Geology, 87, pp. 103-119.

-..-- 1994. Combined-flow generation of sole structures, including recurved groove casts, associated with Lower Carboniferous lacustrine storm deposits in Nova Scotia, Canada. Journal of Sedimentary Research, A64, pp. 508-517.

Martel, A.T., McGregor, D.C., and UtTing, J. 1993. Stratigraphic significance of Upper Devonian and Lower Carboniferous miospores from the type area of Horton Group, Nova Scotia. Canadian Journal of Earth Sciences, 30, pp. 1091-1098.

Miall, A.D. 1977. A review of the braided-river depositional system. Earth Science Review, 13, pp. 1-62.

MooneY, S.J. 1987. Stratigraphy and tectonic evolution of two mid-Paleozoic basins: implications for the timing of final emplacement of the Meguma Terrain. Geological Association Canada-Mineralogical Association Canada, Joint Annual Meeting, Program with Abstracts, 12, p. 74.

Moore, R.G. 1985. Cheverie Formation. In Lexicon of Canadian Stratigraphy, Volume VI, Atlantic Region. Edited by 
G.L. Williams, L.R. Fyffe, R.J. Wardle, S.P. Coleman-Sadd, and R.C. Boehner. Canadian Society of Petroleum Geologists, Calgary, pp 74-75.

-...- 1995. Geology of the Walton-Rainy Cove Brook map area (NTS 21H/01-Z2 and Z4), Hants County, Nova Scotia. Nova Scotia Department of Natural Resources, Mines and Energy Branches, Open File Report 92-022.

Moore, R.G. and Ferguson, S.A. 1986. Geological map of the Windsor area, Nova Scotia. Nova Scotia Department of Mines and Energy, Map 86-2.

MurRay, B.C. 1960. Stratigraphy of the Horton Group in parts of Nova Scotia. Nova Scotia Research Foundation, Halifax, Nova Scotia.

NancE, R.D. 1987. Dextral transpression and late Carboniferous sedimentation in the Fundy coastal zone of southern New Brunswick. In Sedimentary Basins and Basin-Forming Mechanisms. Edited by C. Beaumont and A.J. Tankard. Canadian Society of Petroleum Geology, Memoir 12, pp. 363-377.

Pe-Piper, G., Cormier, R.F., and PiPer, D.W.J. 1989. The age and significance of Carboniferous plutons of the western Cobequid Highlands, Nova Scotia. Canadian Journal of Earth Sciences, 26, pp. 1297-1307.

Pickerill, R.K., CArter, D., and St. Peter, C. 1985. Albert Formation - Oil shales, lakes, fans and deltas. Geological Association Canada-Mineralogical Association Canada, Excursion 6.

Playford, G. 1963. Miospores from the Mississippian Horton Group, Eastern Canada. Geological Survey of Canada, Bulletin 107.

Plint, A.G. and van De Poll, H.W. 1984. Structural and sedimentary history of the Quaco Head area, southern New Brunswick. Canadian Journal of Earth Sciences, 21, pp. 753-761.

Poole, W.H. 1967. Tectonic Evolution of the Appalachian region of Canada. In Geology of the Atlantic Region. Edited by E.R.W. Neale and H. Williams. Geological Association of Canada, Special Paper 4, pp. 9-51.

Prime, G.A. 1987. The Antigonish Basin of Maritime Canada: A sedimentary tectonic history of a Late Paleozoic fault-wedge basin. Unpublished M.Sc. thesis, Dalhousie University, Halifax, Nova Scotia.

Quarch, H., Rikiet, K., and Ryan, R. 1979. Report on geological survey and drilling. Nova Scotia Department of Mines and Energy, Assessment Report 21A/16D - 54I-57(03).

RASt, N. 1984. The Alleghenian orogeny in eastern North America. In Variscan Tectonics of the North Atlantic Region. Edited by D.H.W. Hutton and D.J. Sanderson. Geological Society London, Special Publication 14, pp. 197-217.

Rust, B.R. and Gibling, M.R. 1990. Braidplain evolution in the Pennsylvanian South Bar Formation, Sydney Basin, Nova Scotia, Canada. Journal of Sedimentary Petrology, 60, pp. $59-72$.

SANFORD, B.V. and Grant, A.C. 1990. Bedrock geological mapping and basin studies in the Gulf of St. Lawrence. Geological Survey of Canada, Paper 90-1B, pp. 33-42.

SChenk, P.E. 1991. Events and sea-level changes on Gondwana's margin: The Meguma Zone (Cambrian to Devonian) of Nova Scotia, Canada. Geological Society of America Bulletin, 103, pp. 512-521.

Stemmerik, L. and Worsley, D. 1989. Late Palaeozoic sequence correlations, North Greenland, Svalbard and the Barents Shelf. In Correlation in hydrocarbon exploration. Edited by J.D. Collinson. Graham and Trotman, London, pp. 99-111.

St. Peter, C. 1993. Maritimes Basin evolution: key geologic and seismic evidence from the Moncton Subbasin of New Brunswick. Atlantic Geology, 29, pp. 233-270.

Tate, M.C. and Clarke, D.B. 1993. Origin of the Late Devonian Weekend lamprophyre dykes, Meguma Zone, Nova Scotia. Canadian Journal of Earth Sciences, 30, pp. 2295-2304.

TUNBRIDGE, I.P. 1981. Sandy high-energy flood sedimentation some criteria for recognition, with an example from the Devonian of S.W. England. Sedimentary Geology, 28, pp. 79-95.

Tye, R.S. and Coleman, J.M. 1989. Depositional processes and stratigraphy of fluvially dominated lacustrine deltas: Mississippi Delta plain. Journal of Sedimentary Petrology, 59, pp. 973-996.

UtTing, J. 1987. Palynostratigraphic investigation of the Albert Formation (Lower Carboniferous) of New Brunswick, Canada. Palynology, 11, pp. 73-96.

Utting, J. and Hamblin, A.P. 1991. Thermal maturity of the lower Carboniferous Horton Group, Nova Scotia. International Journal of Coal Geology, 19, pp. 439-456.

Utting, J., Keppie, J.D., and Giles, P.S. 1989. Palynology and stratigraphy of the Lower Carboniferous Horton Group, Nova Scotia. Contributions to Canadian Paleontology, Geological Survey of Canada, Bulletin 396, pp. 117-143.

Waldron, J.W.F., Piper, D.J.W., and Pe-Piper, G. 1989. Deformation of the Cape Chignecto pluton, Cobequid Highlands, Nova Scotia: Thrusting at the Meguma-Avalon boundary. Atlantic Geology, 25, pp. 61-62.

Wightman, W.G., Scott, D.B., Medioli, F.S., and Gibling, M.R. 1994. Agglutinated foraminifera and thecamoebians from the Late Carboniferous Sydney coalfield, Nova Scotia: paleoecology, paleoenvironments and paleogeographical implications. Palaeogeography, Palaeoclimatology, Palaeoecology, 106, pp. 187-202.

WoRTH, J.K. 1969. Stratigraphy of the Horton Bluff Formation, Wolfville, Nova Scotia. Unpublished M.Sc. thesis, Acadia University, Wolfville, Nova Scotia.

\section{APPENDix 1}

\section{Harding Brook Member}

\section{Type section}

The stratotype of the Harding Brook Member crops out

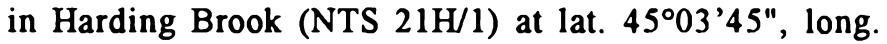
6418'38"; UTM 4990.6 km N, 396.7 km E (Figs. 5, 6). The thickness is about $100 \mathrm{~m}$ at Harding Brook, and the strata correspond approximately to Bell's $(1929,1960)$ basal member of the Horton Bluff Formation.

\section{Correlative sections}

The Harding Brook Member is exposed in a relatively complete correlative section at Duncanson Brook (Fig. 5), and is present in drill core from Upper Falmouth (drill cores S4, S8), and Kennetcook (Soquip Noel \#1 well) (Figs. 2, 4). The Duncanson Brook section and the Saarberg drill cores S4, S8, S9, and S10 all show a general fining-upward pattern from conglomerates near the base to fine- to mediumgrained sandstones near the top. Siltstone and mudstone generally decrease upward within these sections, in a manner similar to the Harding Brook section. Intervals $C$ and $D$ 
are not readily differentiated, however, except at Duncanson Brook. Interval $A$ is well developed in the Duncanson Brook section and in the Saarberg S8, S9 and S10 drill cores, which unconformably overlie deeply weathered granitic rock. See Moore and Ferguson (1986) for location of all Saarberg Drill holes.

\section{Boundaries}

The Harding Brook Member unconformably overlies Devonian granitic rocks in the southeast and Cambrian-Ordovician slates of the Meguma Group in the south and west portion of the subbasin. The upper boundary is not exposed on Harding or Curry brooks, but is placed at a depth of 133 $m$ in Saarberg Interplan drill core S4 from the Upper Falmouth area (Fig. 4). The boundary is drawn where coarsening-upward units show a pronounced increase in the proportion of mudstone, and a decrease in the proportion of thick units of cross-bedded sandstone.

\section{Age}

Utting et al. (1989) and Martel et al. (1993) have documented three miospore zones for the Harding Brook Formation (Fig. 3). Samples from the lowest $0 \mathrm{~m}$ to $8 \mathrm{~m}$ (Fig. 3) contain Late Devonian (late Famennian) miospores of the Retispora lepidospora-Knoxisporites literatus Zone to $R$. lepidophyta-Verrucosisporites nitidus Zone (Martel et al., 1993). The overlying zone between 14.5 to $53.3 \mathrm{~m}$ contains miospores of the early Tournaisian Emphanisporites rotatusIndotriradites explanatus Zone (Martel et al., 1993). The remaining portion of the Harding Brook Member contains late Tournaisian miospores of the Umbonatisporites abstrusus$U$. distinctus subzone of the Vallatisporites vallatus Assemblage Zone (Utting et al., 1989).

\section{Curry Brook Member}

\section{Type section}

The stratotype for this member occurs at Curry Brook

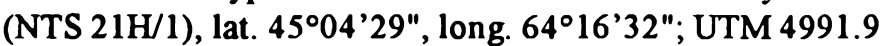
km N, 399.5 km E (Figs. 5, 8). The section at Curry Brook is $120 \mathrm{~m}$ thick and corresponds to the lower portion of Bell's (1929, 1960) middle member.

\section{Correlative sections}

The Curry Brook Member crops out also at Harding Brook, Duncanson Brook, and Upper Falmouth (drill cores S4, S8, S9, and S10), and is known from petroleum exploration drilling at Kennetcook (Soquip Noel \# 1 well) (Fig. 4). As in the Curry Brook section, the Curry Brook Member in Harding Brook coarsens upward from mudstone-dominated (115-136 $\mathrm{m})$ to interbedded mudstone and sandstone $(136-165 \mathrm{~m})$ to sandstone-dominated (136-183 m) strata (Fig. 6). The top of the Curry Brook Member in Curry Brook contains finer beds for a few metres near the top, but the equivalent sec- tion is not exposed in Harding Brook. Despite the similar gross lithological trends, sandstone units could not be correlated individually between the Harding and Curry Brook sections.

\section{Upper boundary}

The upper boundary with the Blue Beach Member is gradational, and coincides approximately with the sandstoneshale contact in Bell's (1960) "middle member". Bell (1960) divided the sandstone (Curry Brook Member) and shale (Blue Beach Member) portions of his middle member at the first occurrence of ostracodes. However, we define the upper Curry Brook boundary at the first appearance of a major, $1.5 \mathrm{~m}$ thick, clay shale which also includes the first occurrence of dolomitic concretions (Fig. 8). The lowermost ostracodes were found $30 \mathrm{~m}$ above this clay shale in the Curry Brook section (Fig. 8).

Age

The Curry Brook Member contains late Tournaisian miospores of the Umbonatisporites abstrusus-U. distinctus subzone of the Vallatisporites vallatus Assemblage Zone (Utting et al., 1989).

\section{Blue Beach Member}

\section{Type section}

The Blue Beach Member stratotype is defined as the lower $156 \mathrm{~m}$ of the Blue Beach section (NTS 21H/1), lat. 4505' 53", long. 64'12'46"; UTM $4994.3 \mathrm{~km} \mathrm{~N}, 404.5 \mathrm{~km}$ E (Figs. 5, 10). Well exposed sections of this member also occur at Tennycape and Walton (Figs. 2, 4). The Blue Beach Member is approximately equivalent to the upper portion of the middle member of Bell $(1929,1960)$ (Table 1).

\section{Correlative sections}

Correlative sections of the Blue Beach Member are found at Curry Brook, Tennycape, Walton (where the strata are highly deformed), Upper Falmouth (drill cores S4, S5, and S6) (Moore and Ferguson, 1986), and Kennetcook (Soquip Noel \#1) (Fig. 4).

\section{Upper boundary}

The upper boundary is gradational. Bell proposed that the boundary between the upper middle (Blue Beach) member and the overlying upper (Hurd Creek) member be placed at the top of the uppermost ostracode-bearing bed. He also noted that this stratigraphic level corresponds with an increase in the proportion of green mudstone and cross-bedded sandstone. MacDonald (1973) proposed that the middleupper member boundary should be placed at the first " $m a-$ jor" sandstone above the thick section of clay shales in the Blue Beach Member. Whereas this provides a logical divid- 
ing line that we followed for this paper (Fig. 10, Table 1), some "major" sandstones pinch out laterally, leading to potential difficulties with the placement of the boundary.

\section{Age}

The Blue Beach Member contains miospores of the Umbonatisporites abstrusus-U. distinctus subzone (lower part), Spelaeotriletes cabotii subzone (upper part), both of which are within the Vallatisporites vallatus Assemblage Zone. The zone is of late Tournaisian age (Utting et al., 1989; Martel et al., 1993).

\section{Hurd Creek Member}

\section{Type section}

The Hurd Creek Member stratotype occurs within the upper portion of Hurd Creek (NTS $21 \mathrm{H} / 1$ ), lat. $45^{\circ} 05^{\prime} 16^{\prime \prime}$, long. 64'13'02"; UTM $4993.4 \mathrm{~km} \mathrm{~N}, 404.0 \mathrm{~km} \mathrm{E}$ (Figs. 5, 12). The member is $64 \mathrm{~m}$ thick at Hurd Creek, although its thickness varies considerably throughout the basin (Fig. 4). The best exposed section of the member occurs at Tennycape, where it is more than $220 \mathrm{~m}$ thick (Fig. 4). The Hurd Creek section was chosen as the type section, however, because it is the best exposure within the type area as defined by Bell (1960) and is close to the type sections of other members. The Hurd Creek Member is approximately equivalent to the upper member of Bell $(1929,1960)$.

\section{Correlative sections}

Correlative sections of the Hurd Creek Member occur at Tennycape, Walton, Blue Beach, and in drill core S5 (Fig. 4). The Hurd Creek Member thickens northward, and appears to thin to the south where the Horton Bluff Formation onlaps onto basement (Fig. 4). On Hurd Creek, the member is dominated by coarsening-upward, sandstone-dominated cycles (Fig. 12). However, to the north at Blue Beach, the member is dominated by coarsening-upward clay shale/siltstone cycles (Fig. 10). MacDonald (1973), Ferguson (1983), and Utting et al. (1989) placed the upper portion of the Blue Beach section within the Blue Beach (upper middle) Member. We favour a correlation of the upper Blue Beach section and the Blue Beach North section with the Hurd Creek (upper) Member (Fig. 4), in agreement with Bell (1960) and Worth (1969). Figure 4 shows the proposed correlation between the Hurd Creek and the Blue Beach and Blue Beach North sections, with sandstones pinching out to the northwest. As the boundary between the Blue Beach and Hurd Creek members is defined on these sandstones, it is probable that the boundary will vary chronologically with the variation in deposition of this facies. Thus the boundary is only dependable locally, and for that reason the units are only given member status.

\section{Upper boundary}

The contact with the overlying arkosic sandstones of the Cheverie Formation has been described as conformable, disconformable, or unconformable (Bell, 1960; Moore, 1985, 1995). We interpret the contact as disconformable at most areas studied, based upon abrupt change in lithology and a lack of angular discontinuity.

Age

The Hurd Creek Member contains miospores of the Spelaeotriletes cabotii subzone of the Vallatisporites vallatus, Assemblage Zone of late Tournaisian age (Utting et al., 1989).

Editorial responsibility: P.S. Giles and G.L. Williams 